\title{
Capital Structure, Pay Structure and Job Termination
}

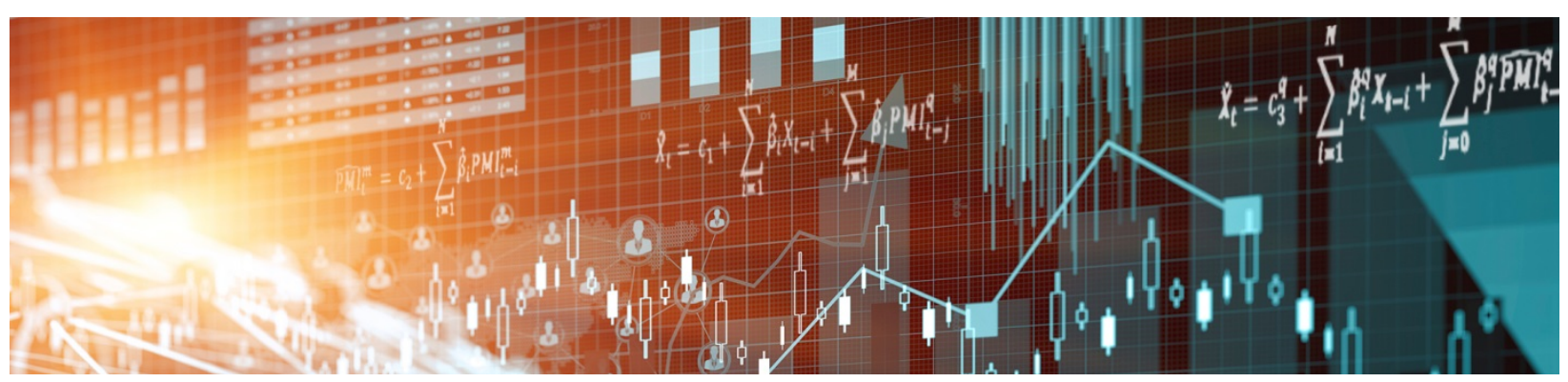

by Jason Allen and James R. Thompson 
Bank of Canada Staff Working Paper 2016-12

March 2016

\title{
Capital Structure, Pay Structure and Job Termination
}

\author{
by \\ Jason Allen ${ }^{1}$ and James R. Thompson ${ }^{2}$ \\ 1Financial Stability Department \\ Bank of Canada \\ Ottawa, Ontario, Canada K1A 0G9 \\ jallen@bankofcanada.ca \\ 2University of Waterloo \\ james@uwaterloo.ca
}




\section{Acknowledgements}

We thank seminar participants at Queen's University and the SFA (2015) for helpful comments. We are extremely grateful to, without implicating, Nellie Gomes and Louis Piergeti at IIROC. We thank Reint Gropp, David Martinez-Miera, Ned Prescott (discussant), Josef Schroth, Jia Xie and Jano Zabojnik for comments. We also thank Andrew Usher for excellent research assistance. 


\begin{abstract}
We develop a model to analyze the link between financial leverage, worker pay structure and the risk of job termination. Contrary to the conventional view, we show that even in the absence of any agency problem among workers, variable pay can be optimal despite workers being risk averse and firms risk neutral. We find that firms employing workers with safer projects (and lower probability of job termination) use more variable compensation, and that leverage is strictly increasing in the amount of variable pay. These two results lead to the main insight of the paper: the more likely it is that a worker is terminated, the lower a firm's leverage. We provide empirical support for these predictions with a novel data set of all Canadian financial brokers and dealers. In the context of our empirical analysis, the model provides a novel mechanism to help explain why high leverage and high amounts of variable pay may be pervasive in financial relative to non-financial institutions.
\end{abstract}

JEL classification: G24, J33

Bank classification: Financial institutions; Labour markets

\title{
Résumé
}

Les auteurs élaborent un modèle permettant d'analyser les liens entre le levier financier, la structure de rémunération et le risque de licenciement. Contrairement à ce qui est généralement admis, ils montrent que, même en l'absence de problème de délégation entre les travailleurs et l'entreprise, une rémunération variable peut être optimale bien que les travailleurs soient réfractaires au risque et que l'entreprise soit neutre à cet égard. Les auteurs constatent que, dans les entreprises où les travailleurs sont employés à des projets plus sûrs (et où la probabilité de licenciement est plus faible), la part de la rémunération variable est plus élevée et le levier financier de l'entreprise augmente parallèlement à cette part. De ces deux constatations ressort le principal résultat de l'étude : plus la probabilité de licenciement est élevée, moins la firme est endettée. Les auteurs présentent une justification empirique de cette prévision à l'aide d'une série inédite de données portant sur l'ensemble des courtiers et négociateurs canadiens en valeurs mobilières. Dans le contexte de leur analyse empirique, le modèle qu'ils proposent offre un nouveau mécanisme expliquant pourquoi un levier financier élevé et une proportion élevée de rémunération variable sont plus répandus chez les sociétés financières que chez leurs homologues non financières.

Classification JEL : G24, J33

Classification de la Banque : Institutions financières; Marchés du travail 


\section{Non-Technical Summary}

This paper develops a theoretical model to analyze the links among financial leverage, pay structure, and job turnover. Using the model, one can rationalize why high leverage and high amounts of variable pay are pervasive in financial relative to non-financial institutions. The main insight of the model is that the more likely worker turnover is, the lower a firm must keep its leverage.

Understanding the relationship among financial leverage, operating leverage, and turnover is crucial for firms since turnover is costly as are deviations from optimal leverage. Our research can better inform firms as to the benefit of using pay structure to create flexibility so as to potentially avoid costly turnover. Furthermore, we show how pay structure can allow for an increase in financial leverage without increasing total firm risk.

The model has three main testable implications. First, variable pay as a fraction of total compensation decreases with the probability of job termination. Second, debt is negatively correlated with the amount of fixed pay and positively correlated with the amount of variable pay relative to fixed pay. Third - the main result of the paper - the higher the probability of job termination, the less debt a firm will employ. We empirically test each of these implications using balance-sheet and income-statement data on the universe of Canadian brokers and dealers from 1992 to 2010. Our empirical results support all three model implications. We therefore uncover a new justification for why banks may be highly levered, and why their wage structure may be more skewed toward variable pay relative to non-financial institutions. What drives both of these results is the fact that banks tend to have lower costs of debt, and lower costs to workers of termination. 


\section{Introduction}

When a worker is risk averse and has a project that is risky, how should a risk-neutral firm pay them? When there is an agency problem, i.e., hidden information or action related to the worker, variable pay can be used to help correct the inefficiency. In the absence of such problems, standard economic theory says that the worker should be paid with fixed pay. In this paper, we re-visit this problem and show that, when the firm's capital structure problem is incorporated, variable pay can arise endogenously, even in the absence of agency problems. We find supporting evidence for our model with a novel data set comprised of all Canadian financial brokers and dealers. Financial institutions offer a particularly useful environment in which to study the implications of our model: we are able to shed new light on why banks may choose high levels of leverage and why they rely heavily on variable pay.

The intuition behind our theoretical results is as follows. Consider workers with risky projects that can either have a high or low return but with no capital for implementation. A firm contracts with workers who have the same project risk and can pay them a variable wage, which is paid only if the return is high, and a fixed wage regardless of the return. Although job termination is endogenous in the model, it is simplest to convey the intuition by assuming that workers are terminated if the return is low; the worker incurs a cost of this termination. In this environment, it is clearly optimal to pay workers with fixed pay since they are risk averse and the firm is risk neutral. The reason is that fixed pay can hedge the low state in which the worker is terminated. Risk aversion implies that the worker receives more utility from fixed wages and therefore the firm minimizes its wage bill by paying through this method.

Now consider a firm that needs to raise money for the projects and does so through debt and equity. Assuming that debt is subsidized relative to equity, in the presence of bankruptcy costs, the firm opts to take on as much debt as possible while avoiding the possibility of bankruptcy in the low state. Fixed pay now works against debt, since it is itself a form of debt on the operation side of the firm. In choosing the amount of fixed pay to offer to workers, the firm trades off the benefit (decreased wage bill from fixed pay due to worker risk aversion) versus the cost (having to reduce debt to avoid the bankruptcy costs). Firms with safer projects (workers), where safer means projects have a higher probability of success, will pay workers with more variable pay. This occurs because the value of fixed pay, in utility terms, is lower for these types of workers, since it is less likely that they are terminated. Thus, our model predicts that firms with safer projects will have more variable pay and higher financial leverage. We uncover these predictions in the data.

We then use the model in the context of banks, which tend to have lower costs of debt 
(Allen et al. (2014)) and lower costs to bankers of being terminated relative to non-financial institutions (Jacobson et al. (1994)). When debt is cheaper, firms have an incentive to use more of it and do so by increasing the amount of variable pay. When the cost of job termination is low, firms use more variable pay since the benefit of fixed pay, in utility terms, is less. This in turn allows firms to take on more debt. These then combine to support two key features of banks that we observe in the real world: high variable pay ${ }^{1}$ and high leverage. ${ }^{2}$

Our work is related to research on the relationship between wage structure and capital structure. Jaggia and Thakor (1994) theoretically explore the relationship between firmspecific human capital and capital structure. Managers choose to exert less effort into firmspecific human capital if their firm has a high probability of going bankrupt. This incentivizes the firm to take on less debt when they value human capital. In contrast, we uncover a relationship between the risk that a worker takes on and capital structure without any agency problem. Thanassoulis (2012) argues that wage structure has important implications for the probability of financial distress. A firm (bank in the context of that paper) prefers to use variable wages to share risk with workers; however, an externality is created because of competition among banks for bankers. ${ }^{3}$ The essence of the risk-sharing incentive in that paper is present in our paper; however, we model heterogenous workers and explicitly consider the capital structure problem. As such, we are able to obtain predictions on what types of firms should have more/less variable wages and higher/lower leverage.

Empirically, Simintzi et al. (2014) provide cross-country evidence that employment protection crowds out financial leverage. The authors hypothesize that higher employment protection increases the costs of financial distress and so debt becomes costlier. Bae et al. (2010) find that firms with "friendlier" policies toward their employees also have less debt. The reason is to reduce leverage risk. ${ }^{4}$ Interestingly, we show that those firms where workers experience higher turnover actually have higher leverage. It is through the compensation channel that operating leverage, i.e., the flexibility of operating expenses to firm conditions, affects capital structure.

Our work is also related to the literature on worker compensation and pay-for-performance, which has largely focused on the role of workers and an agency environment to explain the

1 Lemieux et al. (2009) and Célérier and Vallée (2015) show that, on average, financial institutions pay $65 \%$ of a worker's salary as variable compensation (data from U.S. and France). This compares with 33-41\% in non-financial firms (see Lemieux et al. (2009) and Célérier and Vallée (2015)).

${ }^{2} \mathrm{~A}$ typical debt-to-assets ratio for non-financial corporations is around $20 \%-30 \%$, whereas for financial institutions it is closer to $87 \%-95 \%$ (Gornall and Strebulaev (2014)).

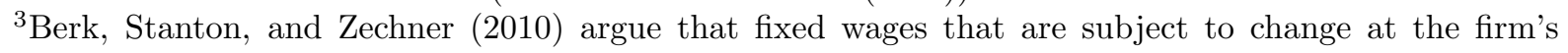
discretion could also avoid bankruptcy.

${ }^{4}$ In contrast, in models by Bronars and Deere (1991), Dasgupta and Sengupta (1993), and Perotti and Spier (1993), high leverage is used to mitigate operational risk by limiting the bargaining power of workers. 
use of variable pay, where fixed pay is often used to offset risk that a worker faces. Early examples include Jensen and Meckling (1976) and Hölmstrom (1979) who focus on compensation and agency costs in explaining risk taking. See Lazear and Oyer (2012) for a summary of the current literature. The empirical evidence is mixed on the trade-off between risk and incentives implied by the standard agency model (Prendergast 1999; Prendergast 2000).

Recently, papers have begun to examine other mechanisms to help explain the prevalence of incentive-based pay. Oyer (2004) constructs a model in which variable pay is used to avoid costly compensation renegotiations. If the outside option of a worker is dependent on firm value, then stock options can prevent a worker from leaving (which is costly to the firm) without the need for renegotiation. In contrast, in our model, the worker is replaceable and so the interim participation constraint does not imply variable wages. Instead, variable pay arises from the firms capital structure problem and not from the worker's problem. Bertrand and Mullainathan (2001) and Gopalan et al. (2010) rationalize CEO pay-for-luck (wherein CEOs are rewarded for sectoral performance and not relative performance) with a skimming model, and with a model in which a CEO needs to choose the degree of correlation that the firm will have with its sector. Again, these papers justify variable pay through a problem related to the worker (a manager in these cases), whereas we show that variable pay can exist solely because of the firm's capital structure decision. It is important to note that although we will not model any agency problems, this is not meant to downplay the potential role of agency costs and incentive pay but rather to better illuminate the mechanism behind our results.

What further sets our theory apart is that we model potential compensation not just for management but all workers. Much of the corporate finance literature on incentives and pay explores management compensation. One reason for this is that data on senior management are more widely available and the effects of CEO compensation and incentives are seemingly easier to disentangle. It is impossible to do justice to this literature; however, three prominent examples include Jensen and Murphy (1990), Hall and Liebman (1998), and Milbourn (2003).

Our empirical work drives the above point further since we have data on non-management workers (in our case, within the Canadian banking industry). Although the popular press focuses on the impressive wages of Russell 3000 executives, which within the broker-dealer category in 2014 was an average of over $\$ 8$ million per year, the typical chief executive in 2014 at a broker-dealer firm earned $\$ 238,740$ in wages (Bureau of Labor Statistics occupational employment statistics NAICS 523100). For the sample of Canadian broker-dealers, the average wage of chief executives in 2014 was Can $\$ 300,828$ (approximately US\$270,745). However, the total wage bill (including cash bonuses) for specialists and analysts is far larger 
than for executives. Staying in Canada, on average, a specialist earns Can $\$ 131,720$ and an analyst Can $\$ 142,534$ per year. In 2014, there were 16,795 specialists and 1,930 analysts compared with 785 top executives. Thus, by focusing only on management wages, much of the literature misses the majority of wages in an organization. This paper will hopefully contribute to a better understanding of variable wages to all workers.

Although our theoretical contribution is general, we present a case study where we examine the financial structure and wage structure of Canadian financial institutions. This is because we have access to detailed firm-level information on the decomposition of wages into their fixed and variable components for these firms. In addition, we have detailed information on financial institutions' balance sheets and income statements. Secondly, our model provides additional theoretic insights into financial institutions' behavior that we discussed above; thus the application to financial institutions seems fruitful.

The remainder of the paper is as follows. Section 2 presents the model of workers and firms, Section 3 provides the main comparative statics, and Section 4 presents the application of the model to financial institutions. In Section 5 we present the data, while Section 6 presents the empirical tests of the model. Section 7 contains an extension of the baseline model that allows for bankruptcy in equilibrium, and finally, Section 8 concludes.

\section{Model}

In this section, we first outline the worker's problem and then solve the firm problem. The model has three key empirical predictions that we test in Section 6 .

\subsection{Worker Problem}

The model is in three periods indexed $t=0,1,2$. We assume that a worker can neither save nor borrow and derives lifetime utility $U$ from periods 1 and 2 , which is given by the exponential function

$$
U=-\sum_{t=1}^{2} \exp \left(-\alpha C_{t}\right)
$$

where $C_{t}$ is consumption in period $t$ and $\alpha$ is the coefficient of absolute risk aversion. Note that we assume for simplicity that utility is additively separable over time and stationary. Without loss of generality (see Section 3.1), we assume that workers do not discount utility over the three periods. 
A worker is penniless but can implement an investment opportunity/project that has a rate of return at $t=1$ of $r_{H}(p)$ with independent and identically distributed (iid) probability $p$ and $r_{L}$ with probability $1-p$, where $r_{H}(p)>r_{L}$. A worker's decision is simple: either engage in the project or take an outside option to be discussed below. We will compare firms that hire workers with different projects. The projects differ in their probability of being in the high state. To this end, let there be a measure 1 of workers that are uniformly distributed along the continuum of project risk level $p$, hence, uniformly distributed on $[0,1]$. Thus, for a given risk level $p$, there is a continuum of workers with the same iid probability of achieving the high return. Given that workers can differ by project risk, it seems reasonable that the return in the high state be a function of project riskiness. We could make the intuitive assumption that $r_{H}^{\prime}(p)<0$, so that safer projects have a lower expected return; however, neither this assumption, nor any assumption on the second derivative, is required to obtain our results. When we analyze the capital structure choice of the firm, it will become clear that the return in the low state plays a role. We could allow firms to differ in this return; however, this would obfuscate the capital structure problem without offering interesting insights into the problem that we consider. We assume that, if the high state occurs, the investment returns $r_{H}(p)$ at $t=2$ as it did at $t=1$. If the low state occurs, then we assume that the investment returns nothing at $t=2$. Thus, it is obvious that, if the investment is in the low state at $t=1$, it will be optimal for the firm to terminate the worker, which we assume comes with a cost $\phi$ to the worker. ${ }^{5}$ For reasons of tractability, we assume that, if the investment is in the high state at $t=1$, the worker bears no cost of being fired; however, this assumption is not crucial. One can imagine that this arises from an (un-modelled) information environment in which worker type is revealed to the market as being high when the state of the world is high, and low when the state of the world is low. ${ }^{6}$ We will maintain this cost as exogenous in the model. The timing and payoffs of the investment are found in Figure 1 .

\footnotetext{
${ }^{5}$ In practice, one might think it would be less costly for the firm to lower wages than terminate workers. As will become clear in Section 3.1. since a project in the low state pays nothing in time $t=2$, a firm would not be willing to pay a worker anything. If the model was relaxed to allow some project value in the low state at $t=2$, then the question of whether to simply cut wages instead of terminating would be present. There is an extensive literature on downward wage rigidities that supports the difficulty firms have cutting wages. Related to our empirical example with financial institutions in Section 6. Bewley (1998) documents how wage cuts impact employee morale, in particular productivity and turnover. We could capture these effects by adding another period to the model in which workers can be productive.

${ }^{6}$ If the worker does have a cost of being fired in the high state, then this would complicate the firm problem (to be outlined below) at $t=0$. One could get around this by adding a cost of firing to the firm, in addition to the worker. When the worker has a cost of firing in both the low and high state, then $\phi$ can also be interpreted as a cost of a worker losing firm-specific human capital.
} 


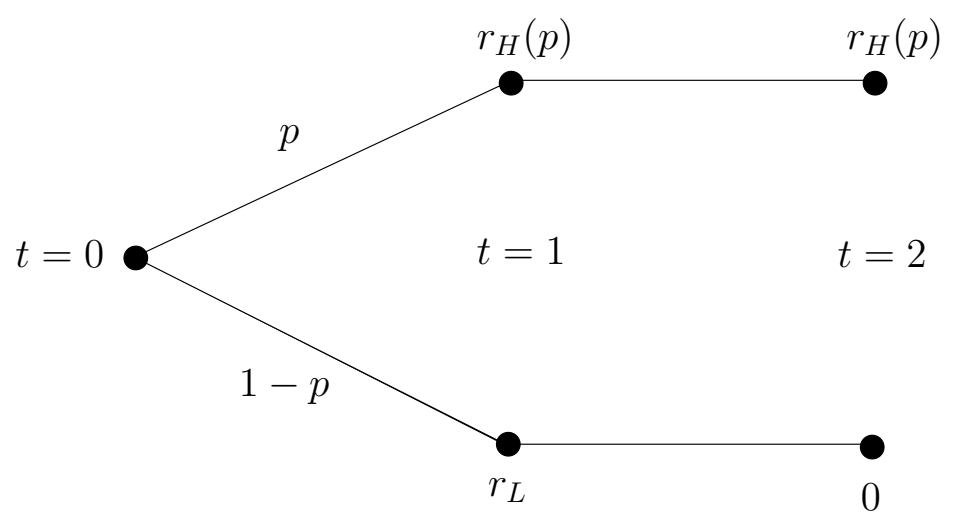

Figure 1: Timing and payoffs of the investment

We assume that the investment opportunity requires an amount of funding that is normalized to one at both $t=0$ and $t=1$. The firm provides the funding for the workers and so the firm is the owner of the project. Workers have an outside option, for example, other employment opportunities, that yields (instantaneous) utility $\underline{u}$, which will be a constraint that must be satisfied at both $t=0$ and $t=1$. For simplicity, we assume that a worker can be replaced without cost at $t=1 .^{7}$ Let the consumption that attains utility $\underline{u}$ be given by $\underline{C}$ such that

$$
\underline{u}=-\exp (-\alpha \underline{C}) .
$$

For what follows, it is simplest to consider the problem between $t=0,1$ and derive the main results of the paper. ${ }^{8}$ In Section 3.1, we solve for the problem between $t=1,2$ and show that a worker is terminated in the low state at $t=1$. This is the only result that we require from the $t=1,2$ problem when analyzing the problem between $t=0,1$. Since workers do not own the equity in the project, they do not receive the proceeds of the investment directly; however, they receive a compensation contract from the firm that pays a fixed amount $F$ at time $t=1$, regardless of the state of the world with respect to the investment, and an amount $V$ when the return is $r_{H}(p)$. We think of $F$ as fixed wages, since they are paid regardless whether the state of the world is $L$ or $H$, and $V$ as variable wages since these are contingent on state $H$. Both $F$ and $V$ will be solved in equilibrium as solutions to the firm's optimization problem outlined below. The utility of a worker at time $t=1$ who invests in a

\footnotetext{
${ }^{7}$ With a cost of replacement, the worker will, not surprisingly, simply receive more compensation in $t=1$. This will not affect the key results in the paper to come. If there were also costs to increasing compensation, then variable pay could be used in a similar way as in Oyer (2004). To maintain focus, we will not consider this mechanism here.

${ }^{8}$ The assumption that the utility function is additively separable implies that utility in one time period does not affect utility in another and so allows us to solve the problem at each time period separately.
} 
project characterized by $p$ is given by

$$
p[u(V+F)]+(1-p)[u(F-\phi)] .
$$

The first term represents the high state of the investment, which occurs with probability $p$. In the high state, the worker receives both variable and fixed wages. The second term represents the low state of the investment, where the worker receives only the fixed wage and suffers the job termination cost $\phi$.

\subsection{Firm Problem}

For our empirical analysis in Section 6, we wish to study firms and their associated workers. We choose to model firm-worker relationships in as simple a way as possible. One could imagine a matching process in which workers of different skills match with firms of different risks. This could create potentially interesting dynamics but would only complicate our analysis. What is important, however, is that firms require workers to implement the projects in both time periods, i.e., the workers are essential in the production process. We assume for simplicity that firms are differentiated by the types of workers that are hired. In other words, firms are differentiated by the riskiness of the projects. To this end, we assume that a firm hires a measure 1 of workers, each with identical $p,{ }^{9}$ and raises the required size 1 of funds. It chooses to raise the funds with debt in the amount of $D$, where the remainder, $1-D$, is equity, $E$. The firm chooses $F$ and $V$ so as to induce the worker to invest in the project. We assume that firms are risk neutral but are subject to a bankruptcy $\operatorname{cost} B$, which can sensitize the firm to default risk. In addition, we make the important assumption that debt is subsidized relative to equity, which will be formalized below. This is a standard assumption in the corporate finance literature driven largely by a perceived tax advantage of debt over equity (see, for example, Graham (2000) and references therein). Since the empirical tests in Section 6 will be performed with data on financial institutions, it is important to point out that this is also a standard assumption in the banking literature (see Gorton and Winton (2003) for a discussion).

\footnotetext{
${ }^{9}$ The implication of $p$ being identical among workers within a given firm is that firm performance is perfectly correlated with worker performance. Alternatively, we could have firms hire from the entire continuum of workers so that each firm has workers with projects of all levels of risk. The key in that case is to differentiate and rank firms based on the average risk of the projects that they possess. All that is needed is positive correlation between worker and firm performance. This relationship is justified based on results starting with Griliches (1957), in which productivity differences across firms could be explained by differences in input quality. In addition, Fox and Smeets (2011) find that differences in labor quality is an important factor in explaining dispersion in firm performance.
} 
Assuming that $r_{H}(p)$ is sufficiently high so that the firm does not fail in the high state, the stark set-up of the model implies that there are two key regions to analyze: the one in which the firm succeeds in the low state, and the one in which it fails. If the firm chooses a sufficiently small level of debt, it will always succeed; thus debt holders will always be paid back. In this case, the required interest rate is constant (denoted $r_{D}$ ) for any amount of debt, while the required rate of return on equity is $r_{E}(D)$, where $r_{E}^{\prime}(D) \geq 0$. ${ }^{10}$ The case of no bankruptcy then occurs when $D \leq \frac{r_{L}-F}{r_{D}}$. Conversely, when $D>\frac{r_{L}-F}{r_{D}}$, the firm fails in the low state. For what follows, we wish to analyze a meaningful capital structure choice of the firm. As such, we consider the case in which the bankruptcy cost is sufficiently large so that the firm does not simply wish to take on debt without bounds. To ease the analysis, we make the starkest assumption possible on the bankruptcy cost $B$ : it wipes out all stakeholders. It should be noted that this is not a necessary assumption.

\section{Assumption $1 B \geq r_{L}$}

Under Assumption 1, when $D>\frac{r_{L}-F}{r_{D}}$, the debt holders receive no payment when the firm fails and so have a constant required interest rate denoted by $\widetilde{r_{D}}>r_{D}$. Similarly, the equity holders do not receive a payoff in the failed state, so that the required rate of return to equity is constant and given by $\widetilde{r_{E}}$. We now formalize the assumption that debt is subsidized relative to equity, which amounts to assuming that the weighted average cost of capital is decreasing in the amount of debt. To analyze the simplest case, we let the subsidy be small. ${ }^{11}$ The following two conditions are derived by differentiating the cost of capital of a firm when it cannot fail, and when it does fail in the low state.

\section{Assumption 2}

$$
\begin{array}{r}
r_{D}-D r_{E}^{\prime}(D)-r_{E}(D)=\epsilon<0, \forall D \in[0,1) \\
\widetilde{r_{D}}-\widetilde{r_{E}}=\epsilon<0, \text { for } \epsilon \text { small. }
\end{array}
$$

We can now write the firm payoff when it can and cannot fail. Consider first the case in which the firm cannot go bankrupt, $D \leq \frac{r_{L}-F}{r_{D}}$. The firm's payoff for a given $\{V, F, D\}$ is

\footnotetext{
${ }^{10}$ Since a firm contracts with workers with the same project characteristics, it is clear that firms will not share the same risk of being in the low state. As will become clear when we give Assumption 1, we simplify the analysis and explore the case in which the firm opts to avoid default. Thus, the interest rate on debt will be independent of $p$. To permit this assumption, it makes sense to let $r_{E}$ be independent of $p$ as well. This is true when, for example, equity holders are risk neutral. We can relax this and allow $r_{E}$ to decrease in $p$ and still obtain our qualitative results to come; however, they will be needlessly obfuscated.

${ }^{11}$ We could derive a sufficient condition under which the subsidy would always be small enough; however, it would involve endogenous variables and so could only be solved for after the equilibrium is established.
} 
given by

$$
p \underbrace{\left[\left(r_{H}(p)-V-F-r_{D} D\right]\right.}_{\text {high state return }}+(1-p) \underbrace{\left[r_{L}-F-r_{D} D\right]}_{\text {low state return }}-\underbrace{r_{E}(1-D)}_{\text {opportunity cost of equity capital. }}
$$

The first term represents the high state of the investment. $r_{H}(p)$ is earned by the firm from the investment, $V+F$ is paid to the workers, $r_{D} D$ is paid to the debt holders. The second term represents the return when the investment is in the low state. Note that only $F$ is paid to the workers in this case. The final term represents the opportunity cost of equity capital. Now consider the case in which the firm goes bankrupt in the low state. The firm's payoff for a given $\{V, F, D\}$ is given by

$$
p\left[r_{H}(p)-V-\widetilde{r_{D}}\right]
$$

where again $\widetilde{r_{D}}>r_{D}$ represents the cost of debt with default risk. The key differences between (6) and (7) is that, when the investment return is low, there is no payoff for the firm when it defaults on its debt. In addition, Assumption 1 implies that, upon defaulting, there is nothing left for the workers nor the debt holders. Therefore, the firm cannot offer a fixed wage and so is restricted to only using variable wages. Note that limited liability implies that the payoff in the low state is zero, even if $B>r_{L}$. We now consider the constrained optimization problem of the firm both when it can and cannot fail. Consider first the case in which it cannot fail, $D \leq \frac{r_{L}-F}{r_{D}}$.

$$
\begin{array}{r}
\max _{V, F, D} \Pi=p\left[r_{H}(p)-V-F-D r_{D}\right]+(1-p)\left[r_{L}-F-D r_{D}(D)\right]-(1-D) r_{E}(D) \\
\text { subject to } p u(V+F)+(1-p) u(F-\phi) \geq \underline{u}, \\
\Pi \geq 0 .
\end{array}
$$

The first constraint represents the restriction that workers must earn at least their reservation utility. Given that a firm's payoff is strictly decreasing in $V$ and $F$, the Kuhn-Tucker conditions imply that the worker constraint must hold with equality. Now consider the problem when the firm fails in the low state, $D>\frac{r_{L}-F}{r_{D}}$.

$$
\begin{array}{r}
\max _{V, F, D} \Pi=p\left[r_{H}(p)-V-D \widetilde{r_{D}}\right]+(1-p)[0]-(1-D) \widetilde{r_{E}} \\
\text { subject to } p u(V)+(1-p) u(-\phi) \geq \underline{u}, \\
\Pi \geq 0 .
\end{array}
$$


We solve this problem in two steps. First we determine $D^{*}$ and then use that to solve the appropriate constrained optimization problem. As a consequence of Assumptions 1 and 2, the firm has only two choices. First, it can choose the highest level of debt that will still maintain its solvency in all states. Alternatively, it can finance the investment exclusively with debt and face the bankruptcy cost in the low state. Note again that we are implicitly considering only the case in which $r_{H}(p)$ is sufficiently large such that the firm is still solvent in the high state, even when $D^{*}=1$. The condition under which this is true is $r_{H}(p)-V-\widetilde{r_{D}}>0$. Clearly, if this condition does not hold, the result is trivial since the equilibrium, if it exists, can never involve bankruptcy. This is because either the worker (requiring $V^{*}$ ) or debt holder (requiring $\widetilde{r_{D}}$ ) can never be paid in full. Note also that we will confirm after the equilibrium analysis that there exists a range of $r_{H}(p)$ such that the firm cannot fail in the high state. We now show formally that Assumptions 1 and 2 imply that the firm will choose the highest amount of debt while still avoiding default.

Lemma 1 The firm sets $D^{*}=\frac{r_{L}-F}{r_{D}}$ and remains solvent in both states.

\section{Proof. See Appendix.}

The intuition behind this result is straightforward. Conditional on no bankruptcy, the firm payoff is increasing in the amount of debt by Assumption 2. Thus, the firm chooses the amount of debt, $D^{*}$, which just ensures it remains solvent. Conditional on bankruptcy, the firm chooses to raise the funds completely with debt. Since Assumption 1 sets bankruptcy costs high, the firm chooses to remain solvent to avoid the cost and so $D^{*}$ prevails as the optimal leverage policy. It is important to point out that, although in our equilibrium the firm does not go bankrupt, we could enrich the model to allow the firm to endogenously choose to go bankrupt with some probability. In Section 7, we consider the project/investment with three potential states instead of two and analyze the case in which the firm chooses to fail in one of the states. We show there that the results to come still hold.

Given that the solution $D^{*}$ implies that equity holders do not receive a payment in the low state, we define the required rate of return simply by $r_{E}$ since it is constant. We can now rewrite the firm optimization problem given the solution for $D^{*}$ from Lemma 1 .

$$
\begin{array}{r}
\max _{V, F} \Pi=p\left[r_{H}(p)-V-F-r_{D} D^{*}\right]-r_{E}\left(1-D^{*}\right) \\
\text { subject to } p u(V+F)+(1-p) u(F-\phi) \geq \underline{u} \\
\Pi \geq 0 .
\end{array}
$$




\section{Equilibrium and Comparative Statics}

We consider the problem outlined in 10 without the non-negativity constraint on the expected payoff of the firm, which we consider in Lemma 2. We obtain the following first-order conditions, where we define the Lagrange multiplier by $\lambda$ :

$$
\begin{array}{r}
V:-p-\lambda p u^{\prime}(V+F)=0 \\
F:-\frac{r_{E}}{r_{D}}-\lambda\left(p u^{\prime}(V+F)+(1-p) u^{\prime}(F-\phi)\right)=0 \\
\lambda: p u(V+F)+(1-p) u(F-\phi)-\underline{u}=0 .
\end{array}
$$

Solving the equations from the first-order conditions (using the fact that utility is exponential) yields the following solutions.

$$
\begin{array}{r}
V^{*}=\frac{\log \left(\frac{r_{E}-p r_{D}}{r_{D} \exp (\alpha \phi)(1-p)}\right)}{\alpha}, \\
F^{*}=\frac{\log \left(\frac{(1-p) r_{E}}{r_{E}-p r_{D}}\right)}{\alpha}+\phi+\underline{C} .
\end{array}
$$

We now restrict the parameter space to implement the $\Pi \geq 0$ in the problem outlined in (10). In addition, we analyze the most interesting case in which the firm uses both variable and fixed pay (i.e., $V^{*}>0$ and $\left.F^{*}>0\right) .{ }^{12}$ The following result derives the necessary and sufficient conditions under which $\Pi \geq 0, V^{*}>0, F^{*}>0$ and proves that parameters exist that satisfy these conditions.

\section{Lemma 2}

- If $r_{H}(p) \geq V^{*}+r_{L}+\frac{r_{E}}{p}\left(1-\frac{r_{L}-F^{*}}{r_{D}}\right)$, then $\Pi \geq 0$.

- If $\frac{r_{E}-p r_{D}}{(1-p) r_{D}}>\exp (\alpha \phi)>\frac{r_{E}-p r_{D}}{(1-p) r_{E} \exp (\alpha \underline{C})}$, then $V^{*}>0$ and $F^{*}>0$.

These conditions hold simultaneously for sufficiently large $\underline{C}$ and $r_{H}(p)$.

The first condition is relatively straightforward. The higher $r_{H}(p)$, the higher the payoff to the firm in the high state. Clearly, a sufficiently large $r_{H}(p)$ can be chosen to ensure that

\footnotetext{
${ }^{12}$ The interpretation of $V^{*}<0$ is that of variable pay in the $L$ state. In particular, the amount of variable pay in the $L$ state is $\left|V^{*}\right|$ and the fixed pay would be $F-\left|V^{*}\right|$. Since we are interested in the most empirically relevant variable pay, we focus only on the case in which total pay is higher in the $H$ state, $V^{*}>0$.
} 
the firm makes non-negative profits, even though the amount they must pay is increasing in $\underline{C}$, the outside option of the worker. Note that this condition ensures that the firm does not fail in the high state. To understand the second condition, consider that, when the cost of job termination is high ( $\phi$ is high), fixed pay is favored since it hedges the state in which the worker is terminated. Alternatively, when the cost of job termination is low, the firm favors variable pay. It is this second case that is most interesting, since in standard models of worker compensation without agency problems, having a risk-neutral firm and a risk-averse worker implies that the worker will receive full insurance through a fixed wage (see, for example, Laffont and Martimort (2002)). To understand how variable pay can be optimal in our setting without an agency problem related to the workers, we rearrange the condition under which $V^{*}>0$ :

$$
\frac{r_{E}}{r_{D}}>\exp (\alpha \phi)(1-p)+p
$$

As the subsidy to debt increases, i.e., $\frac{r_{E}}{r_{D}}$ increases, variable pay becomes more attractive for the firm. In other words, it is the capital structure decision of the firm that can allow variable pay to be optimal. The results that follow will help us understand why: the flexibility of variable pay allows the firm to carry more financial debt, which, if sufficiently subsidized, is desirable. To analyze the most interesting case in which both variable and fixed pay are used, we use Lemma 2 to make the following assumption.

Assumption $3 \frac{r_{E}-p r_{D}}{(1-p) r_{D}}>\exp (\alpha \phi)>\frac{r_{E}-p r_{D}}{(1-p) r_{E} \exp (\alpha \underline{C})}$.

We can now determine how fixed and variable pay change with the riskiness of the projects that the workers of a given firm possess, $p$. This represents the first implication of the model, which is explored empirically in Section 6 .

Lemma 3 Variable pay relative to fixed pay is decreasing in the probability of job termination.

Proof. See Appendix.

The intuition behind the result comes from the risk aversion of the worker. The more likely it is that a worker is terminated (i.e., the more likely it is that the project is of low quality), the more the worker values fixed pay. This is because fixed pay represents insurance against the cost of job termination.

We now explore the relationship between leverage and variable pay. Clearly, both of these are endogenous variables so it should be stressed that this is a correlation result, which 
is explored empirically in Section 6 .

Lemma 4 Debt is negatively correlated with the amount of fixed pay, and positively correlated with the amount of variable pay relative to fixed pay.

Proof. See Appendix.

We show this result by analyzing the relationship between every exogenous variable that affects both the amount of debt and the worker compensation. In each case, the sign of the derivative is the opposite for debt versus that of fixed pay, and the same for debt versus that of variable pay relative to fixed pay. Note that there is one exogenous variable, $r_{L}$, that affects only the amount of debt. To understand this result, it is illuminating to consider the bankruptcy costs of debt, and the fact that debt is subsidized relative to equity. Given these two features, the firm wishes to take on the most debt that it can, while avoiding bankruptcy. Fixed pay is essentially debt on the operating side of the firm. The more fixed pay that the firm uses, the less financial debt that the firm can sustain. Thus, if the relative amount of fixed pay decreases (due to a change in an exogenous parameter of our model), the firm can take on more financial debt. It is now straightforward to give the main implication of our model, which will be explored empirically in Section 6. The following result gives the relationship between the probability of job termination and the capital structure of the firm.

Proposition 1 The higher the probability of job termination, the less debt a firm will employ.

Proof. See Appendix.

The intuition behind this result is found easily by considering Lemmas 3 and 4 . The higher the probability of job termination, the more fixed pay relative to variable pay (and the more fixed pay in absolute terms) that workers will be paid. The more fixed pay, the less debt a firm can employ.

\subsection{The Optimal Decision at $t=1$}

The decision made by the firm between $t=1$ and $t=2$ differs based on whether the worker's investment is in the high or low state. Recall that we assumed that a worker is essential at both time periods, so that the firm must continue to employ workers to realize any payoff at $t=2$. Define $V_{H}^{2}\left(F_{H}^{2}\right)$ as variable (fixed) wage at time $t=2$ if the state is $H$, 
$r_{D}^{2}$ as the required rate of return to debt, and $r_{E}^{2}$ as the required rate of return to equity. If the investment is in the high state, then it returns $r_{H}(p)$ with certainty. Since debt is again assumed to be subsidized, the firm optimally sets $D^{*}=1$ since it cannot go bankrupt. ${ }^{13}$ The firm problem becomes

$$
\max _{V_{H}^{2}, F_{H}^{2}} r_{H}(p)-V_{H}^{2}-F_{H}^{2}-r_{D}^{2} \quad \text { subject to: } u\left(V_{H}^{2}+F_{H}^{2}\right) \geq \underline{u} .
$$

It is straightforward to show that the choice between fixed and variable pay is irrelevant since variable pay is not actually variable. Thus, the solution is simply given by the firm paying the worker $C_{2}=\underline{C}$ with certainty, namely the outside option. If the investment is in the low state, there is no further payoff for the firm, and thus the budget constraint cannot hold since the firm would lose money by paying $\underline{C}$. Thus, it is optimal to terminate the worker. ${ }^{14}$

It is important to recognize that this decision is made at $t=1$ and therefore has no bearing on the decision at $t=0$. If we relaxed the assumption that the worker does not discount utility over the three periods, it will have no effect on the solution at $t=0$.

\section{Applications to Financial Institutions}

Our empirical application in Section 6 tests the results outlined in Section 3 using data from financial institutions. It is therefore worth exploring additional theoretical implications of our model as they apply to these types of firms. Our model is able to rationalize two key features of financial institutions. First, a typical debt-to-assets ratio for non-financial corporations is around $20 \%$ to $30 \%$, whereas for financial institutions it is closer to $87 \%$ to 95\% (Gornall and Strebulaev (2014)). Second, Lemieux et al. (2009) for the U.S. and Célérier and Vallée (2015) for France show that, on average, financial institutions pay 65\% of a worker's salary as variable compensation. This compares with $33 \%$ to $41 \%$ in nonfinancial firms (Lemieux et al. (2009) and Célérier and Vallée (2015), respectively). We show that these two features can arise endogenously through each of two parameters: the

\footnotetext{
${ }^{13}$ In reality, the firm may choose to use profits from the previous period for the investment. Since the capital structure choice at $t=1$ is not particularly important relative to that at $t=0$, we will not pursue this further in detail. One can assume that the firm invests in the debt to account for what is done with the profits from the investment between $t=0$ and $t=1$. Note again that we are implicitly assuming that $r_{H}(p)$ is sufficiently large that the firm is still solvent when $D^{*}=1$. The condition under which this is true is $r_{H}(p)-V_{H}^{2}-F_{H}^{2}-r_{D}^{2}>0$.

${ }^{14}$ Note that a worker still receives the outside option $\underline{C}$ when terminated; however, it is not received from the firm in question.
} 
cost of job termination and the cost of debt. We consider below that both the cost of job termination and the cost of debt is, on average, lower in financial institutions versus non-financial institutions.

\subsection{The Cost of Job Termination}

Consider the cost of job termination within financial institutions; Jacobson et al. (1994) report that, in the U.S., the financial sector is among the lowest in terms of future losses to the worker upon job displacement. Morissette et al. (2007) find similar evidence for Canada. Explanations of why the financial industry has a lower cost to a worker of being displaced typically revolve around the lack of unionization (for example, according to Statistics Canada, the rate of unionization in finance in Canada is around 7.5\%) and the relatively portable skills that finance employees have when moving within industry. ${ }^{15}$ The following result formalizes the relationship in the model.

\section{Corollary 1 The lower the cost of job termination}

$i$. The more variable pay relative to fixed pay a firm will use.

ii. The more debt that a firm will employ.

Proof. See Appendix.

The result is due to the low cost of job termination resulting in a higher level of variable wages, which consequently lead to higher levels of leverage. Therefore, since financial institutions have on average a lower cost of job termination, we should expect to see more variable wages relative to fixed wages and a higher leverage in financial institutions relative to non-financial institutions.

\subsection{The Cost of Debt}

There are a number of reasons why financial firms can enjoy better borrowing rates than those for non-financial firms. Banks that hold deposits receive a subsidy through deposit

\footnotetext{
${ }^{15}$ For example, Morris and Wilhelm (2007) argue that investment bankers posses largely industry-specific human capital and, if there is any firm-specific human capital that exists, it is largely a cultural difference between firms. Even then, investment bankers have reduced the cost by sometimes migrating as teams. Many financial institutions will also penalize bankers who leave voluntarily (but not when they are terminated) by confiscating vested options (thereby increasing switching costs). This practice suggests that the cost of leaving the firm may be low since firms attempt to raise the cost for workers who leave on their own.
} 
insurance (see, for example, Allen et al. (2014)). Broker-dealers, which will the focus of the empirical investigation in Section 6, receive this subsidy indirectly when they are owned by a deposit-taking institution. Financial institutions also tend to have highly liquid debt (Diamond and Dybvig (1983)). The broker-dealers in the data to be introduced in Section 5 have on average approximately $90 \%$ of their liabilities classified as liquid. ${ }^{16}$ In our model, the cost of debt is affected by the bankruptcy cost since that cost directly affects recovery rates. ${ }^{17}$ In addition, financial institutions such as broker-dealers have highly liquid assets in case of fire sales. ${ }^{18}$ Finally, financial institutions tend to have better contract re-enforcement than non-financial institutions (Hölmstrom and Tirole (1997)). The following result relates the cost of debt to the amount of variable pay that a firm will use.

Corollary 2 The lower the cost of debt

i. The more variable pay relative to fixed pay the firm will use.

ii. The more debt a firm will employ.

Proof. See Appendix.

The second part of the result is straightforward: the lower the cost of debt, the more debt a firm wishes to take on. To take advantage of the lower cost of debt, however, the firm lowers the amount of fixed pay it uses to compensate workers to avoid the potential bankruptcy costs. Of course, if fixed pay is lower, the firm must increase variable pay so as to keep the worker at least as well off. Thus, a lower cost of debt of financial institutions works in the same way as a lower cost of job termination: we should expect to see financial institutions employ more debt and more variable pay relative to non-financial institutions.

\section{Data}

The data set we rely on to test the model predictions is a complete proprietary panel of investment brokers and dealers in Canada from January 1992 to December 2010. This

\footnotetext{
${ }^{16}$ Major categories of liabilities include current liabilities (overdrafts, loans payable, securities loans, and repurchase agreements, securities sold short, and client accounts), long-term liabilities (deferred income taxes and capitalized leases), and financial capital.

${ }^{17}$ It is important to note that, although Assumption 1 implies that recovery rates are always zero, it is not a necessary assumption. We can obtain all the results in the paper when recovery rates are positive so that an increase in bankruptcy costs causes the cost of debt to increase.

${ }^{18}$ Liquid assets include cash, loans receivables, securities borrowed and resold, securities owned by the firm and their clients, and clients accounts. Other allowable assets include receivables and recoverable and overpaid taxes. Non-allowable (illiquid) assets include receivables, fixed assets, capitalized leases, and investments in subsidiaries, among other items. Non-allowable assets make up, on average $10 \%$ of assets.
} 
includes banks as well as large and small institutional and retail investors. These data are collected by the Investment Industry Regulatory Organization of Canada (IIROC) and include monthly regulatory financial reports (Form 1 of the IIROC Rule Book). ${ }^{19}$ Income and balance sheet data are reported monthly although we aggregate annually; bonuses are accrued monthly but paid annually, and what is accrued might not actually be awarded. Therefore using monthly data would not be appropriate for analyzing questions related to compensation. IIROC's membership grew from 119 in 1992 to 201 by 2010 but also experienced exits and several mergers. We drop firms that appear for fewer than 5 years and keep track of all mergers. ${ }^{20}$

IIROC is a self-regulatory organization that oversees investment dealer activity in debt and equity markets in Canada as well as personal and wholesale investing. In terms of prudential requirements, IIROC enforces a minimum capital requirement (risk-adjusted capital) and also requires that members hold more margin for assets that are riskier and less liquid. They are also the market-conduct regulators, monitoring dealer behavior, and ensuring members follow a set of Market Integrity Practices that govern issues like front-running and client priority.

IIROC classifies its members into six categories. The criteria of the groups are outlined in Table 1 and are based on size and business orientation. ${ }^{21}$ In the estimating equations, we control for groups, which basically controls for institutional versus retail traders.

Table 1: Groups of investment dealers in Canada (as defined in 2010)

\begin{tabular}{llll}
\hline Group & Regulatory Capital & Clients & Example \\
\hline \hline B & $>\$ 400$ million & Retail and Institutional & BMO Nesbitt Burns \\
$\mathrm{C}$ & $>\$ 5$ million & Institutional & Barclays Capital Canada \\
$\mathrm{D}$ & $>\$ 5$ million & Retail & HSBC Securities Canada \\
$\mathrm{E}$ & $<\$ 5$ million & Institutional & Bloomberg Tradebook Canada \\
$\mathrm{F}$ & $<\$ 5$ million & Retail & yourCFO Advisory Group \\
\hline \hline
\end{tabular}

Table 2 presents summary statistics for the main variables of interest. Summary statistics are collapsed in the cross-section, given that the model predictions are cross-sectional.

\footnotetext{
${ }^{19}$ The Canadian Investor Protection Fund provides insurance of up to $\$ 1$ million against investment dealer insolvency for clients. The blank report schedules are publicly available. http://tinyurl.com/llst4v4.

${ }^{20}$ Many small firms first start off trading only mutual funds and are MFDA members and not IIROC members. In order to trade securities, they join IIROC. However, after several years they terminate their IIROC membership, either returning to trading only mutual funds with their MFDA membership or succumbing to failure. We do not observe the reason for exit.

${ }^{21}$ Excluded from the analysis are what is known as Introducing brokers (group A). Introducing brokers advise clients but must perform transactions through another broker.
} 


\section{Table 2: Summary statistics}

The sample is from 1992 to 2010 . We present the mean, standard deviation, 10th, and 90th percentile after collapsing the data in the cross-section. It includes on average 179 firms. $L$ is total liabilities and $A$ is total assets. $S D$ is subordinated debt. $V W$ is contractual variable wage and Bonus is purely discretionary bonuses, which include bonuses payable to shareholders in accordance with share ownership. $T V W$ denotes total variable wages. Total wages are denoted $T W$. ROA is return on assets. I(dividend) is an indicator variable equal to 1 if the firm issued a dividend and 0 otherwise. I(trading revenue) is an indicator variable equal to one if a bank generated trading revenue. Non-allowable assets are those deemed illiquid by IIROC. All dollar amounts are in 2002 CAD.

\begin{tabular}{lrrrrr}
\hline Variables & mean & sd & p10 & p50 & p90 \\
\hline Leverage ((L+SD)/A) & 62.8 & 28.4 & 17.1 & 71.8 & 93.4 \\
Leverage (L/A) & 60.1 & 29.2 & 15.2 & 69.3 & 92.3 \\
Job termination (\%) & 21 & 41 & 0 & 18 & 43 \\
Bonus/TW (\%) & 14 & 18 & 0 & 6 & 44 \\
VW/TW (\%) & 39 & 28 & 0 & 45 & 73 \\
TVW/TW (\%) & 53 & 25 & 9 & 61 & 79 \\
Fixed wage/employee (\$) & 83,699 & 90,552 & 26,490 & 59,321 & 169,664 \\
Bonus/employee (\$) & 52,960 & 129,801 & 0 & 8,468 & 165,618 \\
VW/employee (\$) & 69,415 & 745,307 & 0 & 57,957 & 154,275 \\
TVW/employee (\$) & 122,375 & 163,343 & 12,202 & 84,517 & 231,905 \\
Number of employees & 223 & 638 & 6 & 34 & 388 \\
ROA & 5.5 & 20.6 & -3.1 & 1.8 & 14.2 \\
Revenue/employee (\$) & 447,370 & $1,103,730$ & 118,460 & 237,850 & 823,100 \\
Profits/employee (\$) & 108,439 & 632,781 & $-6,118$ & 15,451 & 127,262 \\
Revenue/assets & .89 & 1.06 & .07 & 0.40 & 2.41 \\
I(dividend) (\%) & 30 & 32 & & & \\
I(trading revenue) (\%) & 81 & 35 & & & \\
Non-allowable assets/assets (\%) & 11 & 14 & 1 & 6 & 26 \\
\hline
\end{tabular}

However, we also present panel regression results and therefore use some of the time-series variation. Few of the firms in the data set are traded publicly; therefore, we do not use market value of equity to measure leverage. Instead, we use the book value of liabilities over assets. In addition, we introduce a second measure of leverage that incorporates a portion of a financial institutions' subordinated debt. Broker-dealers have two types of subordinated debt on their balance sheet: subordinated loans within the industry and subordinated loans from non-industry investors. We treat the latter as debt and the former as equity. This is because the former is often from the parent (although we cannot distinguish the exact amount) and therefore closer to equity than debt. ${ }^{22}$

\footnotetext{
${ }^{22}$ To prevent the dealers from taking out subordinated debt and simply depositing unused funds at the
} 
Our results are qualitatively similar when industry-subordinated debt is included; however, leverage is substantially higher in some cases. Nevertheless, the average broker-dealer leverage is around $62 \%$ while median leverage is $70 \%$. The 90th-percentile firm leverage is 93\%. Note that Crawford et al. (2009) highlight the role of regulatory limits on assetsto-capital ratios in Canada and therefore lower leverage, on average, for Canadian banks relative to those in the U.K., U.S., and continental Europe. Therefore, leverage as we define it is slightly lower, on average, in our sample relative to what is reported for the United States in Gornall and Strebulaev (2014).

Our measure of job termination is firm-specific. A firm is given a 1 if, at between $t-1$ and $t$, it laid off at least $5 \%$ of its workforce and 0 otherwise. ${ }^{23}$ Our interpretation is that workers in firms with high turnover are more likely to experience job termination. In our econometric specifications, we look at within-firm and between-firm variation in job termination and its correlation with pay and leverage. On average, $21 \%$ of firms experience job termination of at least $5 \%$. Note that, in the data, we cannot separately identify firing from voluntary departures. There are a number of reasons why job termination in this industry, however, might not be considered voluntary. First, almost all firms have a nocompetitor clause, typically 6 months to 1 year if an employee leaves a firm voluntarily. This introduces an important switching cost. In addition, bonuses are often deferred, especially any stock options, which can lead to large switching costs for voluntary departure (Morris and Wilhelm (2007)). ${ }^{24}$ Third, investment bankers do rotate across institutions, but this occurs only when there is strong signalling about their job prospects at their current placement.

For wages, they are decomposed into three segments. ${ }^{25}$ First is fixed wages. Fixed wages are included in total operating expenses. For about a dozen financial institutions, we have the breakdown of operating expenses into wages and other expenses through access to the confidential Canadian tri-agency database managed by the Bank of Canada, the provider of the debt (likely their parent), IIROC introduced a provider of capital concentration charge in January 2000. Standby subordinated loans for the most part found their way into subordinated loans from industry investors where "Industry Investors" refer to individuals who own a beneficial interest in an investment in the Dealer Member or holding company (of the Dealer Member) (IIROC, accessed 2011). By analyzing the capital charges, we are able to determine that within-industry subordinated loans are largely from the parent.

${ }^{23}$ For robustness, we also look at $7.5 \%$ and $10 \%$ and have qualitatively similar results. The idea is to capture firms that lay off a significant fraction of their workforce.

${ }^{24}$ Aldatmaz et al. (2014) find that turnover falls following broad-based employee stock options, although the effect is temporary.

${ }^{25}$ Wages are based on average wages for all non-executive broker-dealers in the firm, irrespective of hierarchy. Efing et al. (2014) do not find that the correlation between variable pay and trading volume/volatilty is sensitive to whether or not wages are equally weighted or weighted by hierarchy within their set of European banks. This provides some assurance that our approach, which is used because of the lack of information on job titles, is sufficient to capture the cross-section heterogeneity in firms' wages. 
Office of the Superintendent of Financial Institutions, and the Canada Deposit Insurance Corporation. Wages are consistently $50 \%$ of operating expenses; therefore, we apply this rule for all financial institutions. This is admittedly ad hoc, but in effect only scales our measure of total wages, given that there is almost no variation in the composition of operating expenses. In addition, there are two types of bonuses. Variable compensation $(V W)$ includes all other bonuses, such as commissions and other bonuses of a contractual nature. Importantly, these are payouts only to registered representatives and institutional and professional trading personnel. Bonuses to management are not included, both discretionary and contractual. Second, there are discretionary bonuses (bonus), which include all discretionary bonuses, including dividends to shareholders (those who are employees).

Total wages is the sum of its three components. In Canadian dollars (deflated using the 1992 consumer price index deflator), the average base (or fixed) wage per employee is approximately $\$ 83,699$ (or approximately $\$ 104,127$ in 2014). Discretionary bonuses are on average $\$ 52,960$ per employee. However, about $10 \%$ of firms never pay a discretionary bonus. Variable wages are on average $\$ 69,415$ per employee and, similar to discretionary bonuses, about $10 \%$ of firms do not pay variable wages. Interestingly, these are not necessarily the same $10 \%$ as those that do not pay discretionary bonuses. Firms that do not pay discretionary bonuses tend to be in group F, i.e., small retail firms. Firms that tend not to pay contractual bonuses tend to be an equal mix of firms in group $\mathrm{F}$ and firms in group C, i.e., large institutional firms. On average, total wages are similar to those reported in the introduction for analysts and specialists.

The average return on assets is 4.74 and there is substantial variation. The ROA for the broker-dealers in this sample is substantially higher than that reported for the banking sector, which is closer to 1 . We report a median ROA of 1.8, however, which is closer to what one would expect in the banking sector. Given the extreme outliers that generate the large differences in the mean and median, we winsorize the data at the $1 \%$ level before estimating our econometric specifications. We also report revenue per employee and revenue per asset. Each employee, on average, generates $\$ 447,370$ per year (approximately $\$ 556,560$ in 2014 dollars) with substantial variation across firms and time. Profits are approximately $\$ 108,000$ per year per employee. An average firm has 223 employees, where employee includes only registered representatives of the firm. A dollar of assets generates about 89 cents of revenue. Finally, about $81 \%$ of firms are involved in trading. A small fraction of firms specialize in only mergers and acquisitions. 


\section{Empirical Results}

Our model of capital structure and pay structure has three testable implications. First is Lemma 3: variable pay as a fraction of total compensation is decreasing in the probability of job termination. Second is Lemma 4 debt is negatively correlated with the amount of fixed pay and positively correlated with the amount of variable pay relative to fixed pay. Finally, Proposition 1 - the main result of the paper - is that the higher the probability of job termination, the less debt a firm will employ. In this section, we present empirical tests for the model's predictions. All three empirical predictions are cross-sectional. Given that our data are annual over a long time period, we present results both from pooled OLS regressions and the between estimator. The pooled OLS estimator takes into account both the cross-section and time-series variation. The between estimator uses only the cross-sectional information by averaging the within-firm information.

Our first regression has total variable wages (variable wage plus discretionary bonuses) as a fraction of total wages as the dependent variable and the main independent variable is the probability of job termination. The prediction from Lemma 3 is that $\beta<0$.

$$
T V W / T W_{i t}=\alpha+\beta \operatorname{pr}(\text { job termination })_{i t}+\gamma X_{i t}+\delta_{j}+\epsilon_{i t}
$$

Included in the $X \mathrm{~s}$ are ROA, log of total assets (size), revenue/assets, an indicator variable for whether or not the firm paid dividends and an indicator variable for whether or not the firm generated trading income; $\delta$ captures group fixed effects where the groups are B-F as defined in Section 5. This variable largely captures whether a firm is institutional versus retail. We include size as a control for several reasons. The main one, however, is that there is evidence that firms offer increasing wage profiles to loosen the effects of financial constraints (Michelacci and Quadrini (2008)). In our context, this implies smaller firms would have a larger fraction of their wage flexible relative to that of the larger firms. The pooled OLS estimator uses all of the information in $i$ and $t$, whereas the between estimator averages the information over $t$, and $\beta$ captures the correlation between wages and the probability of job termination across the $i$ firms.

Results from estimating equation (18) by pooled OLS are presented in column (1) of Table

3. In addition, we present results using a between estimator in column (2) and the marginal effects from the Logit model in column (3), given that some firms do not pay variable wages. The model predictions are in the cross-section; therefore, our main focus is in on column (2). Our variables capture nearly $30 \%$ of the cross-sectional variation in wage structure. Firms that are more likely to have turnover are less likely to use variable wages and therefore more 
likely to use fixed wages. Therefore, this result provides supporting evidence for Lemma 3. How much less? A firm with high turnover pays $27.9 \%$ less variable pay relative to fixed pay than a firm with low turnover. If we look at columns (1) and (3), where we combine the cross-section and time-series data, the impact of job termination on wages is less but still substantial. We can also see that the impact of zeros is minimal, given that the difference in the coefficients from (1) to (3) is negligible.

Lastly, in addition to our main variable of interest, we do not find a positive correlation between size and the wage structure. We do, however, document a positive correlation between total variable compensation and revenue/assets as well as between total variable compensation and dividend payouts. We also document a negative correlation with nonallowable assets (illiquidity) and ROA. The more illiquid a banks' portfolio or the lower the ROA, the higher the fraction of pay that is fixed. This is consistent with results in the next table, Table 4, where we show based on the cross-sectional variation, that job separation and firm risk, measured by volatility in ROA, as well as volatility in firm revenue per assets and firm profits per assets, is positive. ${ }^{26}$ Importantly, the results from Table 4 act as a check on our theory. The model is constructed such that workers with riskier projects are more likely to be terminated. When workers have riskier projects, the corresponding firm should be riskier in the model. Thus, we should expect to see a positive relationship in the data between firm risk and the probability of job separation, which can be seen in Table 4 .

The second estimating equation is given by (19) and has leverage as the dependent variable and the fraction of total compensation as the main independent variable of interest. The model prediction is that $\beta>0$. Strictly speaking, Lemma 4 only states that leverage and variable wages are positively correlated and not that variable wages as a fraction total wages causes leverage. Note that the $X \mathrm{~s}$ and $\delta_{j}$ are as before. We do, however, include lagged leverage in the pooled OLS version to capture the idea that leverage is persistent (Gropp and Heider (2010)).

$$
L_{i t}=\alpha+\rho L_{i, t-1}+\beta(V W / T W)_{i t}+\gamma X_{i t}+\delta_{j}+\epsilon_{i t}
$$

We show results from two approaches, pooled OLS in columns (1)-(2) of Table 5 and a between estimator in columns (3)-(4) of the same table.

The results from Table 5 suggest that leverage is highly persistent. This is consistent with the literature. Second, and the focus of this paper, is that total variable compensation

\footnotetext{
${ }^{26}$ In the model, what is important is that firm risk is the probability of project success, and not liquidation from leverage risk. Empirically, there is no exact counterpart. We therefore measure risk in the probability of project success using three different balance sheet figures: volatility in revenues, profits, and return on assets.
} 


\section{Table 3: Testing Lemma 3: variable pay relative to fixed pay is decreasing in the probability of job termination}

The dependent variable is total variable wage $(T V W)$, defined as discretionary bonuses plus contractual bonuses, divided by total wage $(T W)$. I(dividend) is an indicator equal to 1 if the firm pays out a dividend and 0 otherwise. Non-allowable assets is the fraction of a bank's assets that are illiquid. I(trading income) is an indicator variable equal to 1 if the firm generates trading income and 0 otherwise. ROA is return on assets. Data are by firm-year. There are on average 178 firms. Standard errors in the pooled OLS regression are clustered at the firm times year level and calculated using the bootstrap for the between estimator. The levels of significance are ${ }^{* * *} \mathrm{p}<0.01,{ }^{* *} \mathrm{p}<0.05,{ }^{*} \mathrm{p}<0.1$.

\begin{tabular}{|c|c|c|c|}
\hline VARIABLES & $\begin{array}{c}(1) \\
\text { pooled OLS }\end{array}$ & $\begin{array}{c}(2) \\
\text { between estimator }\end{array}$ & $\begin{array}{c}(3) \\
\operatorname{logit}\end{array}$ \\
\hline $\operatorname{Pr}($ job termination $)$ & $\begin{array}{c}-0.0927^{* * *} \\
(0.0179)\end{array}$ & $\begin{array}{c}-0.279^{* * *} \\
(0.100)\end{array}$ & $\begin{array}{c}-0.0960^{* * *} \\
(0.0148)\end{array}$ \\
\hline $\log ($ total assets $)$ & $\begin{array}{c}0.00366 \\
(0.00641)\end{array}$ & $\begin{array}{l}-0.00518 \\
(0.00789)\end{array}$ & $\begin{array}{c}0.00430 \\
(0.00262)\end{array}$ \\
\hline $\mathrm{I}($ dividend $)$ & $\begin{array}{c}0.0349 \\
(0.0238)\end{array}$ & $\begin{array}{c}0.172^{* * *} \\
(0.0491)\end{array}$ & $\begin{array}{c}0.0360^{* * *} \\
(0.0129)\end{array}$ \\
\hline Revenue/assets & $\begin{array}{c}0.0883 * * * \\
(0.0167)\end{array}$ & $\begin{array}{c}0.0905 * * * \\
(0.0214)\end{array}$ & $\begin{array}{c}0.0984^{* * *} \\
(0.00950)\end{array}$ \\
\hline Non-allowable assets ( $\%)$ & $\begin{array}{c}-0.346^{* *} \\
(0.134)\end{array}$ & $\begin{array}{c}-0.370^{* * *} \\
(0.139)\end{array}$ & $\begin{array}{c}-0.375^{* * *} \\
(0.0605)\end{array}$ \\
\hline $\mathrm{I}($ trading income $)$ & $\begin{array}{c}0.140^{* * *} \\
(0.0444)\end{array}$ & $\begin{array}{c}0.195^{* * *} \\
(0.0561)\end{array}$ & $\begin{array}{c}0.143^{* * *} \\
(0.0196)\end{array}$ \\
\hline $\mathrm{ROA}$ & $\begin{array}{c}-0.00167^{* *} \\
(0.000745)\end{array}$ & $\begin{array}{c}-0.00595^{* * *} \\
(0.00195)\end{array}$ & $\begin{array}{c}-0.00183^{* * *} \\
(0.000534)\end{array}$ \\
\hline Constant & $\begin{array}{c}0.346^{* * *} \\
(0.119)\end{array}$ & $\begin{array}{c}0.450^{* * *} \\
(0.153)\end{array}$ & \\
\hline $\begin{array}{l}\text { Observations } \\
R^{2}\end{array}$ & $\begin{array}{l}1757 \\
0.155\end{array}$ & $\begin{array}{l}1757 \\
0.289\end{array}$ & 1757 \\
\hline
\end{tabular}

is positively correlated with leverage, both the liabilities-to-assets ratio and the liabilities plus subordinated debt-to-assets ratio. In addition, leverage is positively correlated with size but negatively correlated with non-allowable (illiquid) assets as well as trading income. This last result would suggest that firms involved in trading are less levered than firms that are more involved in other activities, such as mergers and acquisitions. However, this is not the case. Unconditionally, firms involved in trading are more levered, 68:1 versus 62:1.

Finally, the third estimating equation tests our main proposition. The dependent variable is leverage as in equation (19) and the main independent variable of interest is the probability 


\section{Table 4: Relationship between probability of job separation and firm risk}

The dependent variable is one of three within firm measures: (i) standard deviation of revenue per assets, (ii) standard deviation of profits per assets, and (iii) standard deviation of ROA. Estimates are based on the between estimator. I(dividend) is an indicator equal to 1 if the firm pays out a dividend and 0 otherwise. Non-allowable assets is the fraction of a bank's assets that are illiquid. I(trading income) is an indicator variable equal to 1 if the firm generates trading income and 0 otherwise. Data are by firm-year. There are on average 178 firms. Standard errors are calculated using the bootstrap. The levels of significance are $* * *$ $\mathrm{p}<0.01,{ }^{* *} \mathrm{p}<0.05,{ }^{*} \mathrm{p}<0.1$.

\begin{tabular}{lccc}
\hline VARIABLES & $\sigma$ (rev/assets) & $\sigma$ (profits/assets) & $\sigma(\mathrm{ROA})$ \\
\hline & & & \\
Pr(job termination) & 0.194 & $0.164^{* *}$ & $16.40^{* *}$ \\
& $(0.131)$ & $(0.0806)$ & $(8.056)$ \\
I(dividend) & $0.308^{*}$ & $0.157^{*}$ & $15.74^{*}$ \\
& $(0.162)$ & $(0.0875)$ & $(8.754)$ \\
Non-allowable assets (\%) & $0.952^{* *}$ & $0.321^{* *}$ & $32.12^{* *}$ \\
& $(0.376)$ & $(0.152)$ & $(15.19)$ \\
I(trading income) & $0.108^{*}$ & 0.0515 & 5.155 \\
& $(0.0577)$ & $(0.0350)$ & $(3.500)$ \\
Constant & 0.00614 & -0.0383 & -3.832 \\
& $(0.0875)$ & $(0.0460)$ & $(4.605)$ \\
& & & \\
Observations & 1756 & 1756 & 1756 \\
$R^{2}$ & 0.113 & 0.074 & 0.074 \\
\hline
\end{tabular}

of job termination. Proposition 1 states that the coefficient $\beta<0$.

$$
L_{i t}=\alpha+\rho L_{i, t-1}+\beta \operatorname{pr}(\text { job termination })_{i t}+\gamma X_{i t}+\delta_{i}+\epsilon_{i t} .
$$

The results are shown in Table 6. In addition to the pooled OLS and between estimator, we present results for the fixed effects estimator. Lemmon et al. (2008), among others, highlight the importance of unobserved firm heterogeneity being the primary driver of leverage. Gropp and Heider (2010) do so specifically for banks. They attribute this to banks targeting a fixed, unobserved leverage ratio. Excluding the lag implies that banks are at their optimal leverage ratio and that there are no adjustment costs. Introducing the lag, however, can lead to biased estimates if leverage is measured with error at $t$ and $t-1$.

Our results support Proposition 1. Firms with higher probabilities of job termination have lower leverage. This effect is in addition to the obvious impact of size on leverage and what one might expect to be the impact of size on job turnover. Given two firms with an average leverage of approximately 63:1, our results suggest that the firm with high turnover has a leverage ratio closer to 50:1. 


\section{Table 5: Testing Lemma 4: debt is positively correlated with the amount of variable pay relative to fixed pay}

Total variable pay is defined as discretionary bonus plus contractual variable compensation. $L / A$ is total liabilities over total assets. $(L+S D) / A$ is total liabilities plus subordinated loans from non-industry investors. Excluded from our definition of sub-debt is subordinated loans from industry investors, including the parent. We treat this as equity. I(dividend) is an indicator equal to 1 if the firm pays out a dividend and 0 otherwise. Non-allowable assets is the fraction of a bank's assets that are illiquid. I(trading revenue) is an indicator variable equal to 1 if the firm generates trading income and 0 otherwise. $R O A$ is return on assets. Data are by firm-year. There are on average 178 firms. Standard errors in the pooled OLS regression are clustered at the firm times year level and calculated using the bootstrap for the between estimator. The levels of significance are ${ }^{* * *} \mathrm{p}<0.01,{ }^{* *} \mathrm{p}<0.05,{ }^{*} \mathrm{p}<0.1$.

\begin{tabular}{|c|c|c|c|c|}
\hline VARIABLES & $\begin{array}{c}(1) \\
(\mathrm{L}+\mathrm{SD}) / \mathrm{A} \\
\text { pooled }\end{array}$ & $\begin{array}{l}\quad(2) \\
\mathrm{L} / \mathrm{A} \\
\text { OLS }\end{array}$ & $\begin{array}{c}(3) \\
(\mathrm{L}+\mathrm{SD}) / \mathrm{A} \\
\text { Between }\end{array}$ & $\begin{array}{c}(4) \\
\mathrm{L} / \mathrm{A} \\
\text { stimator }\end{array}$ \\
\hline Leverage $_{t-1}$ & $\begin{array}{c}0.626^{* * *} \\
(0.0452)\end{array}$ & $\begin{array}{c}0.613^{* * *} \\
(0.0441)\end{array}$ & & \\
\hline (total variable pay)/total & $\begin{array}{c}7.784^{* * *} \\
(1.670)\end{array}$ & $\begin{array}{c}8.775^{* * *} \\
(1.782)\end{array}$ & $\begin{array}{l}13.23^{* *} \\
(5.433)\end{array}$ & $\begin{array}{c}16.19^{* * *} \\
(5.140)\end{array}$ \\
\hline $\log$ (total assets) & $\begin{array}{c}1.864^{* * *} \\
(0.330)\end{array}$ & $\begin{array}{c}2.000^{* * *} \\
(0.333)\end{array}$ & $\begin{array}{c}5.290^{* * *} \\
(0.612)\end{array}$ & $\begin{array}{c}5.449^{* * *} \\
(0.579)\end{array}$ \\
\hline I(dividend) & $\begin{array}{l}1.319^{*} \\
(0.780)\end{array}$ & $\begin{array}{l}1.230 \\
(0.831)\end{array}$ & $\begin{array}{c}2.251 \\
(4.268)\end{array}$ & $\begin{array}{c}4.132 \\
(4.037)\end{array}$ \\
\hline Revenue/assets & $\begin{array}{c}-2.139^{* *} \\
(0.851)\end{array}$ & $\begin{array}{c}-2.057^{* *} \\
(0.863)\end{array}$ & $\begin{array}{l}-1.470 \\
(1.733)\end{array}$ & $\begin{array}{l}-2.353 \\
(1.639)\end{array}$ \\
\hline Non-allowable assets (\%) & $\begin{array}{c}-39.40^{* * *} \\
(6.943)\end{array}$ & $\begin{array}{c}-45.61^{* * *} \\
(6.858)\end{array}$ & $\begin{array}{c}-93.61^{* * *} \\
(10.07)\end{array}$ & $\begin{array}{c}-106.1^{* * *} \\
(9.529)\end{array}$ \\
\hline I(trading income) & $\begin{array}{l}-2.235^{*} \\
(1.230)\end{array}$ & $\begin{array}{c}-2.436^{* *} \\
(1.234)\end{array}$ & $\begin{array}{c}-7.517^{* *} \\
(3.664)\end{array}$ & $\begin{array}{c}-8.554^{* *} \\
(3.466)\end{array}$ \\
\hline ROA & $\begin{array}{c}-0.127^{* * * *} \\
(0.0437)\end{array}$ & $\begin{array}{l}-0.0847^{*} \\
(0.0430)\end{array}$ & $\begin{array}{c}-0.629^{* * *} \\
(0.143)\end{array}$ & $\begin{array}{c}-0.426^{* * *} \\
(0.136)\end{array}$ \\
\hline Constant & $\begin{array}{c}-5.211 \\
(5.540)\end{array}$ & $\begin{array}{l}-7.465 \\
(5.632)\end{array}$ & $\begin{array}{l}-15.21 \\
(11.37)\end{array}$ & $\begin{array}{l}-20.71^{*} \\
(10.76)\end{array}$ \\
\hline $\begin{array}{l}\text { Observations } \\
R^{2}\end{array}$ & $\begin{array}{l}1571 \\
0.822\end{array}$ & $\begin{array}{l}1571 \\
0.825\end{array}$ & $\begin{array}{c}1757 \\
0.708\end{array}$ & $\begin{array}{l}1757 \\
0.753\end{array}$ \\
\hline
\end{tabular}


Table 6: Testing Proposition 1: the higher the probability of job termination, the less debt that a firm will employ

$L / A$ is total liabilities over total assets. $(L+S D) / A$ is total liabilities plus subordinated loans from nonindustry investors. Excluded from our definition of sub-debt is subordinated loans from industry investors, including the parent. We treat this as equity. I(dividend) is an indicator equal to 1 if the firm pays out a dividend and 0 otherwise. $\mathrm{I}$ (trading income) is an indicator variable equal to 1 if the firm generates trading income and 0 otherwise. Non-allowable assets is the fraction of a bank's assets that are illiquid. Data are by firm-year. There are on average 178 firms. Standard errors in the pooled OLS regression are clustered at the firm times year level, clustered at the firm level for the fixed-effects estimator, and calculated using the bootstrap for the between estimator. The levels of significance are ${ }^{* * *} \mathrm{p}<0.01,{ }^{* *} \mathrm{p}<0.05,{ }^{*} \mathrm{p}<0.1$

\begin{tabular}{|c|c|c|c|c|c|c|}
\hline VARIABLES & $\begin{array}{c}(1) \\
(\mathrm{L}+\mathrm{SD}) / \mathrm{A} \\
\text { Pooled OLS } \\
\end{array}$ & $\begin{array}{c}(2) \\
\text { L/A } \\
\text { Pooled OLS }\end{array}$ & $\begin{array}{c}(3) \\
(\mathrm{L}+\mathrm{SD}) / \mathrm{A} \\
\mathrm{FE}\end{array}$ & $\begin{array}{c}(4) \\
\mathrm{L} / \mathrm{A} \\
\mathrm{FE} \\
\end{array}$ & $\begin{array}{c}(5) \\
(\mathrm{L}+\mathrm{SD}) / \mathrm{A} \\
\mathrm{BE}\end{array}$ & $\begin{array}{c}(6) \\
\mathrm{L} / \mathrm{A} \\
\mathrm{BE} \\
\end{array}$ \\
\hline Leverage $_{t-1}$ & $\begin{array}{l}0.636^{* * *} \\
(0.0457)\end{array}$ & $\begin{array}{c}0.626^{* * * *} \\
(0.0448)\end{array}$ & $\begin{array}{l}0.269^{* * *} \\
(0.0192)\end{array}$ & $\begin{array}{c}0.268^{* * * *} \\
(0.0187)\end{array}$ & & \\
\hline $\operatorname{Pr}($ job separation $)$ & $\begin{array}{c}-4.565^{* * * *} \\
(0.925)\end{array}$ & $\begin{array}{c}-4.886^{* * *} \\
(0.938)\end{array}$ & $\begin{array}{c}-2.740 * * * \\
(0.656)\end{array}$ & $\begin{array}{c}-2.857^{* * *} \\
(0.667)\end{array}$ & $\begin{array}{l}-13.35^{*} \\
(7.102)\end{array}$ & $\begin{array}{c}-17.15^{* *} \\
(6.737)\end{array}$ \\
\hline $\log$ (total assets) & $\begin{array}{c}1.779 * * * \\
(0.313)\end{array}$ & $\begin{array}{c}1.902^{* * * *} \\
(0.313)\end{array}$ & $\begin{array}{c}6.947^{* * *} \\
(0.403)\end{array}$ & $\begin{array}{c}8.190^{* * * *} \\
(0.414)\end{array}$ & $\begin{array}{c}5.044^{* * * *} \\
(0.630)\end{array}$ & $\begin{array}{c}5.133^{* * *} \\
(0.597)\end{array}$ \\
\hline I(dividend) & $\begin{array}{l}1.405^{*} \\
(0.772)\end{array}$ & $\begin{array}{l}1.326 \\
(0.820)\end{array}$ & $\begin{array}{c}2.046^{* * *} \\
(0.704)\end{array}$ & $\begin{array}{l}1.214^{*} \\
(0.715)\end{array}$ & $\begin{array}{c}4.377 \\
(4.189)\end{array}$ & $\begin{array}{l}6.721^{*} \\
(3.974)\end{array}$ \\
\hline Revenue/assets & $\begin{array}{l}-1.565^{*} \\
(0.814)\end{array}$ & $\begin{array}{l}-1.403^{*} \\
(0.823)\end{array}$ & $\begin{array}{c}-5.512^{* * *} \\
(0.705)\end{array}$ & $\begin{array}{c}-4.549 * * * \\
(0.717)\end{array}$ & $\begin{array}{l}-0.742 \\
(1.685)\end{array}$ & $\begin{array}{l}-1.502 \\
(1.599)\end{array}$ \\
\hline Non-allowable assets (\%) & $\begin{array}{c}-40.60^{* * *} \\
(7.043)\end{array}$ & $\begin{array}{c}-46.85^{* * *} \\
(6.920)\end{array}$ & $\begin{array}{c}-64.57^{* * *} \\
(4.165)\end{array}$ & $\begin{array}{c}-66.58^{* * *} \\
(4.222)\end{array}$ & $\begin{array}{c}-98.07^{* * *} \\
(9.929)\end{array}$ & $\begin{array}{c}-111.5^{* * *} \\
(9.420)\end{array}$ \\
\hline $\mathrm{I}$ (trading income) & $\begin{array}{c}-0.972 \\
(1.210)\end{array}$ & $\begin{array}{l}-1.020 \\
(1.246)\end{array}$ & $\begin{array}{l}-1.101 \\
(1.352)\end{array}$ & $\begin{array}{l}-0.901 \\
(1.374)\end{array}$ & $\begin{array}{l}-4.887 \\
(3.534)\end{array}$ & $\begin{array}{l}-5.331 \\
(3.353)\end{array}$ \\
\hline $\mathrm{ROA}$ & $\begin{array}{c}-0.137^{* * *} \\
(0.0434)\end{array}$ & $\begin{array}{c}-0.0966^{* *} \\
(0.0428)\end{array}$ & $\begin{array}{l}-0.0460^{*} \\
(0.0262)\end{array}$ & $\begin{array}{l}-0.0216 \\
(0.0266)\end{array}$ & $\begin{array}{c}-0.694^{* * *} \\
(0.140)\end{array}$ & $\begin{array}{c}-0.505^{* * *} \\
(0.133)\end{array}$ \\
\hline Constant & $\begin{array}{l}-0.482 \\
(5.323)\end{array}$ & $\begin{array}{l}-2.200 \\
(5.327)\end{array}$ & $\begin{array}{c}-63.20^{* * *} \\
(7.202)\end{array}$ & $\begin{array}{c}-86.86^{* * *} \\
(7.352)\end{array}$ & $\begin{array}{l}-3.903 \\
(12.00)\end{array}$ & $\begin{array}{l}-6.430 \\
(11.38)\end{array}$ \\
\hline $\begin{array}{l}\text { Observations } \\
R^{2}\end{array}$ & $\begin{array}{c}1571 \\
0.823\end{array}$ & $\begin{array}{l}1571 \\
0.824\end{array}$ & $\begin{array}{c}1571 \\
0.522\end{array}$ & $\begin{array}{l}1571 \\
0.550\end{array}$ & $\begin{array}{l}1757 \\
0.704\end{array}$ & $\begin{array}{l}1757 \\
0.748\end{array}$ \\
\hline
\end{tabular}




\section{Robustness}

We modify the model to show that, in equilibrium, the firm has a positive probability of bankruptcy. To accomplish this in the simplest way possible, we add one new element to the model. In addition to the $H$ and $L$ states at time $t=1$, we add a state $M$. Let the probability that state $H$ occurs be $p_{H}$, the probability of state $L$ be $p_{L}$ and, consequently, the probability of state $M, p_{M}$, is $1-p_{H}-p_{L}$. Let the return in state $M$ be $r_{M}$ where $r_{H}\left(p_{H}\right)>r_{M}>r_{L}$. We assume that debt is subsidized, and let $B \geq r_{M}$. The firm offers a compensation contract that promises to pay $F$ in all states, and $V$ only in state $H$. As before, let $r_{D}$ represent the interest rate on debt without default, and $r_{E}$ represent the cost of equity in that case. If a firm chooses not to default on debt in any state, it sets $D=\frac{r_{L}-F}{r_{D}}$ because of the subsidy to debt, and the firm payoff for a given $\{\mathrm{V}, \mathrm{F}\}$ in this case is

$$
p_{h}\left(r_{H}(p)-V-r_{L}\right)+p_{M}(1-p)\left(r_{M}-r_{L}\right)-r_{E}\left(1-\frac{r_{L}-F}{r_{D}}\right) \text {. }
$$

Next, consider the case in which the firm defaults on the debt only in state $L$. Let $\widetilde{r_{D}} \geq r_{D}$ $\left(\widetilde{r_{E}} \geq r_{E}\right)$ be the interest rate (cost of equity) in the presence of bankruptcy costs $B$ with failure only in state $L$. Given that debt is subsidized, the firm sets $D=\frac{r_{M}-F}{\widetilde{r_{D}}}$ so as to remain solvent in state $M$. The firm's payoff for a given $\{\mathrm{V}, \mathrm{F}\}$ is

$$
p_{H}\left(r_{H}(p)-V-r_{M}\right)-\widetilde{r_{E}}\left(1-\frac{r_{M}-F}{\widetilde{r_{D}}}\right) \text {. }
$$

Finally, the firm may default on its debt in both states $M$ and $L$. Define $\widehat{r_{D}} \geq \widetilde{r_{D}}$ as the cost of debt, given that the firm defaults in states $M$ and $L$. In this case, the firm sets $D=1$. The firm's payoff for a given $\{\mathrm{V}, \mathrm{F}\}$ is

$$
p_{H}\left(r_{H}(p)-V-F-\widehat{r_{D}}\right) .
$$

The following result shows that 22 can yield the highest payoff for a firm.

Lemma 5 There exist parameters such that a firm with workers characterized by projects with risk defined by $p_{H}, p_{M}$, and $p_{L}$ sets debt equal to $\frac{r_{M}-F}{\widetilde{r_{D}}}$ and defaults with probability $p_{L}$. Proof. See Appendix.

The intuition behind this result is that a firm chooses to default in state $L$ because the benefits of using more debt (i.e., the subsidy to debt) outweighs the bankruptcy costs 
associated with the failure. Conversely, the firm chooses not to default on the debt in state $M$ because the cost of bankruptcy in that state outweighs the benefit of increased debt. To show that the results of the paper do not change when a firm can go bankrupt, we are left with defining a worker's problem. Importantly, we need to consider time $t=2$. When the return to the project is zero at $t=2$ in both states $M$ and $L$, then the problem is identical to the base model, where $1-p$ is replaced by $1-p_{H}$. Thus, all the results remain unchanged. Conversely, if in state $M$ there is a sufficient return at $t=2$ so that the worker is not terminated (i.e., the return is sufficiently high such that it is optimal to pay workers their outside option), then the worker problem, which constitutes the constraint in (10), involves another distinct term. Consequently, the new $V^{*}$ and $F^{*}$ are slightly altered; however, they share the same properties as before and, consequently, the results of the paper still hold.

\section{Conclusion}

We provide a new model that links worker job termination, pay structure (variable versus fixed), and the capital structure of the firm. The model produces three testable implications, for which we find empirical support using a novel data set composed of all Canadian investment brokers and dealers. We show that firms that are less likely to dismiss workers will pay more variable wages. This is despite there being no agency problems. Once we take into account the firm's capital structure decision, variable pay arises endogenously. We find that firms paying more variable wages have higher leverage, and so firms that are more likely to dismiss workers have lower leverage. We then use the model in the context of financial institutions and uncover a new justification for why banks may be highly levered, and why their wage structure may be more skewed toward variable pay relative to non-financial institutions. What drives both of these results is the fact that banks tend to have lower costs of debt, and lower costs to workers of termination.

Although this paper does not model any agency problems, such issues likely play a role in many firms. An interesting future direction is to embed agency costs into the model and to differentiate between management and workers. As data availability improves, we can then disentangle the use of variable pay into its role in ameliorating agency conflicts and its use in enhancing financial flexibility as shown in this paper. Another future direction is to consider stock options versus variable pay. Although stock options may be relegated to management in many organizations, there are firms, such as financial firms, that pay workers partly with such options. In the context of our model, if stock options are granted ex ante with an exercise price such that they pay off in the $H$ state, but not in the $L$ state, then the results will be qualitatively similar to those from our model. If stock options are granted ex 
post, then the model would need to consider additional periods to capture how the option value evolves. Interestingly, if our model was relaxed to allow heterogeneity among workers, the payoff of stock options could, for example, be high at the same time a worker's project is in the $L$ state. In that case, stock options would actually be a hedge against the state in which the worker is dismissed, thus performing the same function as fixed pay. In any case, the operating flexibility that stock options would create could allow more debt through the same mechanism explored in this paper. 


\section{Appendix}

Proof of Lemma 1

Define $V_{N D}$ and $F_{N D}$ as variable and fixed wages, respectively, when the firm does not default. Define $V_{D}$ as variable wages when the firm does default. We first show that, in any equilibrium, $V_{D}>V_{N D}+F_{N D}$. From problem (8), the worker constraint that binds in equilibrium is

$$
p u\left(V_{N D}+F_{N D}\right)+(1-p) u\left(F_{N D}-\phi\right)=\underline{u} .
$$

From problem (9), the worker constraint is

$$
p u\left(V_{D}\right)+(1-p) u(-\phi)=\underline{u} .
$$

Since $u^{\prime}>0$, it follows that $V_{D}>V_{N D}+F_{N D}$. Assumption 2 implies that the optimal debt level conditional on no default is $D_{N D}^{*}=\frac{r_{L}-F}{r_{D}}$, while $D_{D}^{*}=1$ is optimal when the firm defaults in the low state. Comparing (6) and (7) yields the following condition under which the payoff to the bank with no default exceeds that with default:

$$
-p\left(V_{D}-V_{N D}-F_{N D}\right) \leq-r_{E}+p \widetilde{r_{D}}
$$

Since both $\widetilde{r_{D}}$ and $\widetilde{r_{E}}$ are constant, and neither debt nor equity holders receive anything in the low state, the only difference between the required rates is the subsidy to debt. Since equity holders receive nothing in the low state with or without default, it follows that $r_{E}=\widetilde{r_{E}}$. Consider the limiting case in which the subsidy to debt approaches 0 . Since $\widetilde{r_{E}}$ is an expected rate of return and $\widetilde{r_{D}}$ is an interest rate (in the high state), it follows that $\widetilde{r_{D}} \rightarrow(1 / p) r_{E}$. Therefore, 27) becomes

$$
-p\left(V_{D}-V_{N D}-F_{N D}\right) \leq r_{E} D_{N D}^{*}
$$

which holds since $V_{D}-V_{N D}-F_{N D}>0$ and $r_{E} D_{N D}^{*}>0$.

Proof of Lemma 3

$$
\frac{d F^{*}}{d p}=-\frac{r_{E}-r_{D}}{\alpha(1-p)\left(r_{E}-p r_{D}\right)}<0
$$


where the inequality follows from $r_{E}>r_{D}$.

$$
\frac{d V^{*}}{d p}=\frac{r_{E}-r_{D}}{\alpha(1-p)\left(r_{E}-p r_{D}\right)}>0,
$$

where the inequality follows from $r_{E}>r_{D}$. It then follows that $\frac{d\left(V^{*} / F^{*}\right)}{d p}>0$ since $F^{*}>0$ and $V^{*}>0$ by Assumption 3 .

Proof of Lemma 4

We consider how all parameters change with $F^{*}, V^{*} / F^{*}$, and $D^{*}$. The proof to Corollary 1 shows that $\frac{d F^{*}}{d \phi}=1>0, \frac{d\left(V^{*} / F^{*}\right)}{d \phi}<0$, and $\frac{d D^{*}}{d \phi}<0$. The proof to Corollary 2 shows that $\frac{d F^{*}}{d r_{D}}<0, \frac{d\left(V^{*} / F^{*}\right)}{d r_{D}}<0$, and $\frac{d D^{*}}{d r_{D}}>0$. The proof to Lemma 3 shows that $\frac{d F^{*}}{d p}<0, \frac{d\left(V^{*} / F^{*}\right)}{d p}>0$. Since $D^{*}=\frac{r_{L}-F^{*}}{r_{D}}$, it follows that $\frac{d D^{*}}{d p}>0$. Next, it is trivial to see that $\frac{d F^{*}}{d \underline{C}}>0, \frac{d\left(V^{*} / F^{*}\right)}{d \underline{C}}<0$ and, since $D^{*}=\frac{r_{L}-F^{*}}{r_{D}}$, it follows that $\frac{d D^{*}}{d \underline{C}}<0$. Now consider $\alpha$ :

$$
\begin{aligned}
\frac{d F^{*}}{d \alpha} & =-\frac{\log \left(\frac{r_{E}-p r_{E}}{r_{E}-p r_{D}}\right)}{\alpha^{2}}>0 \\
\frac{d V^{*}}{d \alpha} & =-\frac{\log \left(\frac{r_{E}-p r_{D}}{r_{D}-p r_{D}}\right)}{\alpha^{2}}<0,
\end{aligned}
$$

where the inequality in 28 follows since $\frac{r_{E}-p r_{E}}{r_{E}-p r_{D}}<1$, and the inequality in 29) follows since $\frac{r_{E}-p r_{D}}{r_{D}-p r_{D}}>1$. It follows that $\frac{d\left(V^{*} / F^{*}\right)}{d \alpha}<0$. Since $D^{*}=\frac{r_{L}-F^{*}}{r_{D}}$, it follows that $\frac{d D^{*}}{d \alpha}<0$. Next consider $r_{E}$ :

$$
\begin{array}{r}
\frac{d F^{*}}{d r_{E}}=-\frac{p r_{D}}{\alpha r_{E}\left(r_{E}-p r_{D}\right)}<0 \\
\frac{d V^{*}}{d r_{E}}=\frac{1}{r_{E}-p r_{D}}>0 .
\end{array}
$$

It follows that $\frac{d\left(V^{*} / F^{*}\right)}{d \alpha}>0$. Since $D^{*}=\frac{r_{L}-F^{*}}{r_{D}}$, it follows that $\frac{d D^{*}}{d r_{E}}>0$. Finally, $F^{*}$ and $V^{*}$ are independent of $r_{L}$ while it is trivial to see that $D^{*}$ is increasing in $r_{L}$. It follows that, for every parameter in $V^{*}$ and $F^{*}, F^{*}$ is negatively correlated with $D^{*}$ and $V^{*} / F^{*}$ is positively correlated with $D^{*}$.

Proof of Proposition 1 


$$
\frac{d D^{*}}{d p}=\frac{d D^{*}}{d\left(V^{*} / F^{*}\right)} \frac{d\left(V^{*} / F^{*}\right)}{d p}<0
$$

where the inequality follows from Lemma 3 and Lemma 4.

Proof of Corollary 1

Part 1: $\frac{d V^{*}}{d \phi}=-1<0, \frac{d F^{*}}{d \phi}=1>0$; therefore $\frac{d\left(V^{*} / F^{*}\right)}{d \phi}<0$ since $F^{*}>0$ and $V^{*}>0$ by Assumption 3 .

Part 2: Since $\frac{d\left(V^{*} / F^{*}\right)}{d \phi}<0$, Lemma 4 implies $\frac{d D^{*}}{d \phi}=\frac{d D}{d V} \frac{d V}{d \phi}<0$.

\section{Proof of Corollary 2}

Part 1: It is straightforward to show that $\frac{d V^{*}}{d r_{D}}>0, \frac{d F^{*}}{d r_{D}}<0$ and so $\frac{d\left(V^{*} / F^{*}\right)}{d r_{D}}<0$ since $V^{*}>0$ and $F^{*}>0$ by Assumption 3 .

Part 2: Since $D^{*}=\frac{r_{L}-F}{r_{D}}$ and both $r_{D}$ and $F$ decrease, it is clear that debt increases.

Proof of Lemma 5

Let $\widetilde{r_{D}^{N B}}$ be the interest rate that a firm pays when there are no bankruptcy costs and the firm defaults in the state $L . \widetilde{r_{E}^{N B}}$ is then the corresponding cost of equity.

$$
\left(p_{H}+p_{M}+p_{L}\right)\left(r_{L}-F\right)+r_{E}\left(1-\frac{r_{L}-F}{r_{D}}\right) \geq\left(p_{H}+p_{M}\right)\left(r_{M}-F\right)+\widetilde{r_{E}^{N B}}\left(1-\frac{r_{M}-F}{\widetilde{r_{D}^{N B}}}\right)
$$

The first terms on both sides of the above inequality are the payments to debt holders where, for example, with no failure, the amount received by debt holders in all states is $\frac{r_{L}-F}{r_{D}} r_{D}$. Now consider the environment with bankruptcy costs. Comparing (22) with (21) and (22) 
with (23) yields the following two conditions under which a firm chooses to default only in state $L$ :

$$
\begin{array}{r}
\left(p_{H}+p_{M}\right)\left(r_{M}-r_{L}\right) \leq p_{H}\left(V_{D 1}^{*}-V_{N D}^{*}\right)+r_{E}\left(1-\frac{r_{L}-F_{N D}^{*}}{r_{D}}\right)-\widetilde{r_{E}}\left(1-\frac{r_{M}-F_{D 1}^{*}}{\widetilde{r_{D}}}\right) \\
p_{H}\left(\widehat{r_{D}}\right) \geq p_{H}\left(V_{D 1}^{*}-V_{D 2}^{*}+r_{M}\right)+\widetilde{r_{E}}\left(1-\frac{r_{M}-F_{D 1}^{*}}{\widetilde{r_{D}}}\right) .
\end{array}
$$

Where $V_{N D}^{*}\left(F_{N D}^{*}\right)$ is the equilibrium variable (fixed) wage when the firm does not default, $V_{D 1}^{*}\left(F_{D 1}^{*}\right)$ is the equilibrium variable (fixed wage) when the firm defaults in the low state. Note that a fixed wage in this context is one that pays in the high and medium states only. Finally, $V_{D 2}^{*}$ is the variable wage if the firm defaults in both the medium and low states. Note that no fixed wage can be paid in this case. To show that parameters exist such that (34) and (35) can be satisfied, let $p_{L} \rightarrow 0$; thus $\widetilde{r_{D}} \rightarrow \widetilde{r_{D}^{N B}}, \widetilde{r_{E}} \rightarrow \widetilde{r_{E}^{N B}}, \widetilde{r_{D}^{N B}} \rightarrow r_{D}, \widetilde{r_{E}^{N B}} \rightarrow r_{E}$, and it is straightforward to show that in equilibrium, $V_{D 1}^{*} \rightarrow V_{N D}^{*}$. Using these, conditions (34) and (33) collapse to the same inequality and so (34) must be satisfied. From (35) we get

$$
\widehat{r_{D}} \geq V_{D 1}^{*}-V_{D 2}^{*}+r_{M}+\frac{\widetilde{r_{E}}}{p_{H}}\left(1-\frac{r_{M}-F_{D 1}^{*}}{r_{D}}\right)
$$

which holds when the subsidy to debt is sufficiently small so that $\widehat{r_{D}}$ is sufficiently close to $\frac{1}{p_{H}} \widetilde{r_{E}}$. 


\section{References}

Aldatmaz, S., P. Ouimet, and E. Van Wesep (2014). The option to quit: The effect of employee stock options on turnover. CES working paper No. 14-06.

Allen, F., E. Carletti, and R. Marquez (2014). Deposits and bank capital structure. mimeo.

Bae, K.-H., J.-K. Kang, and J. Wing (2010). Employee treatment and firm leverage: A test of the stakeholder theory of capital structure. Journal of Financial Economics 100, $130-153$.

Berk, J., R. Stanton, and J. Zechner (2010). Human capital, bankruptcy, and capital structure. Journal of Finance 65, 891-926.

Bertrand, M. and S. Mullainathan (2001). Are CEOs rewarded for luck? The ones without principles are. The Quarterly Journal of Economics 116, 901 - 932.

Bewley, T. (1998). Why not cut pay? European Economic Review 42, 459- 490.

Bronars, S. and D. Deere (1991). The threat of unionization, the use of debt, and the preservation of shareholder wealth. The Quarterly Journal of Economics 106, 231 254.

Célérier, C. and B. Vallée (2015). Returns to talent and the finance wage premium. mimeo.

Crawford, A., C. Graham, and E. Bordeleau (2009). Regulatory constraints on leverage: The Canadian experience. Bank of Canada Financial System Review (June).

Dasgupta, S. and K. Sengupta (1993). Sunk investment, bargaining and choice of capital structure. International Economic Review 34, 203 - 220.

Diamond, D. and P. Dybvig (1983). Bank runs, deposit insurance, and liquidity. Journal of Political Economy 91, $401-419$.

Efing, M., H. Hau, P. Kampkötter, and J. Steinbrecher (2014). Incentive pay and bank risktaking: Evidence from Austrian, German, and Swiss banks. Journal of International Economics 96, S123 - S140.

Fox, J. and V. Smeets (2011). Does input quality drive measured differences in firm productivity? International Economic Review 42, 961 - 989.

Gopalan, R., T. Milbourn, and F. Song (2010). Strategic flexibility and the optimality of pay for sector performance. The Review of Financial Studies 23, 2060 - 2098.

Gornall, W. and I. Strebulaev (2014). Financing as a supply chain: the capital structure of banks and borrowers. Rock Center for Corporate Governance at Stanford working paper No. 166. 
Gorton, G. and A. Winton (2003). Financial intermediation. In G. Constantinides, M. Harris, and R. Stulz (Eds.), Handbook of the Economics of Finance, Part A. Amsterdam: North Holland.

Graham, J. (2000). How big are the tax benefits of debt? Journal of Finance 60, 1901 1942.

Griliches (1957). Specification bias in estimation of production functions. Journal of Farm Economics 39, 8- 20.

Gropp, R. and F. Heider (2010). The determinants of bank capital structure. Review of Finance 14, 587-622.

Hall, B. and J. Liebman (1998). Are CEOs really paid like bureaucrats? Quarterly Journal of Economics 111, 653 - 691.

Hölmstrom, B. (1979). Moral hazard and observability. Bell Journal of Economics 10, 74 $-91$.

Hölmstrom, B. and J. Tirole (1997). Financial intermediation, loanable funds, and the real sector. Quarterly Journal of Economics 112, 653 - 691.

Jacobson, L., R. Lalonde, and D. Sullivan (1994). Earnings losses of displaced workers. American Economic Review 83, 685-709.

Jaggia, P. and A. Thakor (1994). Firm-specific human capital and optimal capital structure. International Economic Review 35, 283-308.

Jensen, M. and W. Meckling (1976). Theory of firm: managerial behaviour, agency costs and capital structure. Journal of Financial Economics 3, 305-360.

Jensen, M. and K. Murphy (1990). Performance pay and top-management incentives. Journal of Political Economy 98, 225 - 264.

Laffont, J.-G. and D. Martimort (2002). The Theory of Incentives: The Principal Agent Model. Princeton University Press.

Lazear, E. and P. Oyer (2012). Personnel Economics. In R. Gibbons and D. J. Robert (Eds.), Handbook of Organizational Economics, Chapter 13. Princeton University Press.

Lemieux, T., W. Macleod, and D. Parent (2009). Performance pay and wage inequality. Quarterly Journal of Economics 124, 1 - 49.

Lemmon, M., M. Roberts, and J. Zender (2008). Back to the beginning: Persistence and the cross-section of corporate capital structure. Journal of Finance 63, 1575-1608. 
Michelacci, C. and V. Quadrini (2008). Financial markets and wages. Review of Economic Studies 76, $795-827$.

Milbourn, T. (2003). CEO reputation and stock-based compensation. Journal of Financial Economics 68, $233-262$.

Morissette, R., X. Zhang, and M. Frenette (2007). Earnings losses of displaced workers: Canadian evidence from a large administrative database on firm closures and mass layoffs. Statistics Canada. Cat no. IIFOO19MIE - No. 291.

Morris, A. and W. Wilhelm (2007). Investment Banking: Institutions, Politics, and Law. Oxford University Press.

Oyer, P. (2004). Why do firms use incentives that have no incentive effects? Journal of Finance 4, 1619-1650.

Perotti, E. and K. Spier (1993). Capital structure as a bargaining tool: The role of leverage in contract renegotiation. American Economic Review 83, 1131 - 1141.

Prendergast, C. (1999). The provision of incentives in firms. Journal of Economic Literature $37,7-63$.

Prendergast, C. (2000). What trade-off of risk and incentives? American Economic Review $90,421-425$.

Simintzi, E., V. Vig, and P. Volpin (2014). Labor protection and leverage. Forthcoming Review of Financial Studies.

Thanassoulis, J. (2012). The case for intervening in banker's pay. Journal of Finance 67, 849-895. 